IZA DP No. 5941

The Effect of Variable Pay Schemes on Workplace Absenteeism

Konstantinos Pouliakas

Nikolaos Theodoropoulos

August 2011

Forschungsinstitut zur Zukunft der Arbeit Institute for the Study of Labor 


\title{
The Effect of Variable Pay Schemes on Workplace Absenteeism
}

\author{
Konstantinos Pouliakas \\ University of Aberdeen Business School \\ and IZA \\ Nikolaos Theodoropoulos \\ University of Cyprus
}

\section{Discussion Paper No. 5941 \\ August 2011}

\author{
IZA \\ P.O. Box 7240 \\ 53072 Bonn \\ Germany \\ Phone: +49-228-3894-0 \\ Fax: +49-228-3894-180 \\ E-mail: iza@iza.org
}

Any opinions expressed here are those of the author(s) and not those of IZA. Research published in this series may include views on policy, but the institute itself takes no institutional policy positions.

The Institute for the Study of Labor (IZA) in Bonn is a local and virtual international research center and a place of communication between science, politics and business. IZA is an independent nonprofit organization supported by Deutsche Post Foundation. The center is associated with the University of Bonn and offers a stimulating research environment through its international network, workshops and conferences, data service, project support, research visits and doctoral program. IZA engages in (i) original and internationally competitive research in all fields of labor economics, (ii) development of policy concepts, and (iii) dissemination of research results and concepts to the interested public.

IZA Discussion Papers often represent preliminary work and are circulated to encourage discussion. Citation of such a paper should account for its provisional character. A revised version may be available directly from the author. 


\section{ABSTRACT}

\section{The Effect of Variable Pay Schemes on Workplace Absenteeism*}

We estimate the effect of variable pay schemes on workplace absenteeism using two cross sections of British establishments. Private sector establishments that explicitly link pay with individual performance are found to have significantly lower absence rates. This effect is stronger for establishments that offer variable pay schemes to a greater share of their nonmanagerial workforce. Matched employer-employee data suggest that the effect is robust to a number of sensitivity tests. We also find that firms that tie a greater proportion of employees' earnings to variable pay schemes are also found to experience lower absence rates. Further, quintile regression results suggest that variable pay schemes have a stronger effect on establishments with an absence rate that is higher than an average or "sustainable" level. Finally, panel data suggest that a feedback mechanism is present, whereby high absenteeism in the past is related to a greater future incidence of individual variable pay schemes, which, in turn, is correlated with lower absence rates.

JEL Classification: J22, J33, C21

Keywords: performance-related pay, absenteeism, incentives, Britain

Corresponding author:

Konstantinos Pouliakas

European Centre for the Development of Vocational Training (Cedefop)

Europe 123

Thessaloniki 57001

Greece

E-mail: Konstantinos.Pouliakas@cedefop.europa.eu

\footnotetext{
* This work contains statistical data from ONS which is Crown copyright and reproduced with the permission of the controller of HMSO and Queen's Printer for Scotland. The use of the ONS statistical data in this work does not imply the endorsement of the ONS in relation to the interpretation or analysis of the statistical data. This work uses research datasets which may not exactly reproduce National Statistics aggregates. We thank the sponsors of the Workplace Employment Relations Survey (WERS) - Department for Business Enterprise and Regulatory Reform, ACAS, ESRC and PSI - and the UK Data Archive for access to the WERS data. We are also grateful to A. Bryson, J. Forth, T. Barmby, L. Christofides, C. Pissarides, J. Skatun, I. Theodossiou, P. Tsakloglou, A. Zangelidis, N. Ziros and seminar participants at the University of Aberdeen Business School, Athens University of Economics and Business, University of Cyprus, Royal Economic Society (Surrey, 2010), IZA Summer Symposium on Labour Economics (2010), the National Institute of Economic and Social Research (NIESR) and at the Society of Labor Economists (Vancouver, 2011) for useful comments. The usual disclaimer applies.
} 


\section{Introduction}

There is an increasing amount of interest in recent years on the economics of absenteeism. This has been spurred mainly by a growing awareness that the economic and social costs (e.g. sickness benefits, health care, early retirement) of the phenomenon are considerable. Estimates of the direct cost of absenteeism for the UK economy, which exclude difficult to quantify effects such as the impact on work climate and production bottlenecks, have exhibited an upward trend in recent decades. For example, they have risen from $£ 6$ billion per year in the 1980s (Brown and Sessions 1996) to $£ 11.6$ billion in 1993 (Barham and Begum 2005) and $£ 17$ billion in 2009 (Chartered Institute of Personnel and Development 2009). In most advanced economies absenteeism is now believed to account for economic losses of approximately 2-3 percent of Gross Domestic Product, or a typical year's growth (EUROFOUND 1997; Edwards and Greasley 2010). At a policy level the UK and other governments have also become increasingly concerned with the escalating number of people claiming sickness and incapacity benefits, a phenomenon that has overwhelmed social security budgets. For instance, expenditure on sickness and incapacity benefits, standing at $£ 16 \mathrm{bn}$ in 2002 , was four-times greater than the respective amount devoted to unemployment insurance (Department for Work and Pensions 2002).

While economists have focused in the past on elements of the job contract that interact with the cost of absence, such as the basic wage and sick pay replacement rates (Barmby et al. 1991, Johansson and Palme 1996; Henrekson and Persson 2004), an examination of the impact of performance-related pay (PRP) schemes on absence rates has been neglected. The continued prevalence of contingent pay ${ }^{1}$ schemes in modern British organizations has been extensively noted (Millward et al. 1992; Pendleton et al. 2009). Though such schemes have traditionally taken the form of incentives tied to individual (objective or subjective) output (e.g. payment by results, merit pay), collective schemes based on wider measures of performance (e.g. group or workplace bonuses) and more aggregate "shared capitalist"

\footnotetext{
${ }^{1}$ We use the terms PRP, variable pay and contingent pay interchangeably.
} 
schemes (e.g. profit-related pay, share-ownership) have become increasingly common (Bryson and Freeman 2010). However, due to data constraints many studies in the past have examined the impact of a catch-all measure of PRP on the absenteeism of specific firms or industries (Wilson and Peel 1991; Brown et al. 1999; Engellandt and Riphahn 2011). This has confounded the effect of individual measures of PRP on absenteeism in most cases, and has prohibited the detection of the exact incentive power of dissimilar types of PRP schemes.

This paper examines the effect of a wide and heterogeneous set of PRP measures on the absence rates of private sector British firms. ${ }^{2}$ It uses data from two cross-sections (1998 and 2004) of the Workplace Employee Relations Survey (WERS), a merged subsample of the 2004 WERS data with the Annual Survey of Hours and Earnings (ASHE) and the 1998-2004 WERS Panel Survey. ${ }^{3}$ This permits the investigation of the nature of the relationship between a variety of PRP instruments (including their coverage and intensity) and absenteeism. The WERS is a representative dataset of British establishments that offers a wide range of workplace characteristics with which we attempt to comprehensively capture firm heterogeneity. It also permits the matching of employer-employee information when necessary. Given the sparse previous literature on the effects of variable pay schemes on absenteeism, which has typically relied on a narrowly defined population (e.g. a single firm or plants within a firm, Brown 1994; Barmby et al. 1995) there is a clear need for using large nationally-representative samples to examine the topic. Despite its shortcomings, the WERS with its questions pertaining to variable pay schemes, workplace absence and numerous firm characteristics provides a particularly rich source of information that allows us to examine the relationship between absenteeism and PRP. Further, the two cross sections and the WERS panel allow us to examine the absenteeism-PRP relationship at different points in time.

\footnotetext{
${ }^{2}$ We use the terms establishments, firms and workplaces interchangeably.

${ }^{3}$ Belfield and Marsden (2003) utilize the 1998 WERS and the 1990-1998 WERS panel to study performance pay, monitoring and establishment performance. Arrowsmith and Marginson (2011) utilize the 2004 WERS to study variable pay and collective bargaining.
} 
We show that, ceteris paribus, firms that employ PRP wage schemes that are tied primarily to the assessment of individual merit and performance are characterized by significantly lower absence rates. This negative relation becomes stronger in firms that offer PRP to a greater proportion of their nonmanagerial workforce, and as the share of workers' earnings that is subject to variable pay rises. A series of sensitivity tests confirm that the negative relation of PRP with absence is robust to selectivity and to the inclusion of administrative measures of earnings and working hours and the injury and illness rate of establishments. It is also found to be robust to organization fixed effects, which implies that the negative effect of individual PRP on absence persists even among highly similar establishments that are part of the same organization. Further, quintile regression results suggest that PRP has an asymmetric effect on absence. We find that PRP has a stronger effect at establishments that have an absence rate that exceeds a typical average level of absence. Finally, evidence of a causal chain of reaction is detected, indicating that firms that suffer from high absence rates in the past are more likely to subsequently adopt individual PRP schemes. The same firms are, in turn, observed to benefit from lower current levels of absenteeism.

The structure of the paper is as follows. Section 2 reviews the hypothesized relation between performance pay and absenteeism, an important indicator of firm performance. Section 3 describes the data. Section 4 presents the empirical estimates of the absenteeism-PRP relationship, while Sections 5 and 6 engage in a number of important sensitivity and endogeneity tests that exploit the WERS-ASHE and 1998-2004 WERS Panel Surveys, respectively. Finally, Section 7 concludes.

\section{PRP and Absenteeism}

Economists originally viewed the absence phenomenon as a manifestation of the labour supply decisions of employees (Allen 1981). Therefore, greater attention was paid to how hours of work adjust to economic incentives such as wages and statutory sick pay (e.g. Barmby et al. 1991). Several demographic characteristics of workers have also been identified as important predictors of absenteeism, such as being female or of young age (Vistnes 1997; Dione and Dostie 2007). Other researchers have 
examined whether there is a "disciplining" impact of unemployment on attendance behavior (Leigh 1985; Barmby et al. 1994; Arai and Thoursie 2005). Recently, economists have turned their focus to the demand side of the market, and most notably to firm characteristics that are argued to affect the cost of absence. Typical examples include working time schedules (Brown and Sessions 1996), unionization (Allen 1984), “assembly line" technologies (Coles and Tremble 1996; Coles et al. 2007), teamwork (Heywood and Jirjahn 2004; Heywood et al. 2008), and firm size (Barmby and Stephan 2000).

Despite the fact that Allen (1981) identified merit wage increases and attendance bonuses as two potential "weapons" that firms can use for raising the penalty of employee absence, an examination of the impact of different PRP schemes on absenteeism has been sparse in the literature. According to the standard principal-agent model, firms will attempt to combat moral hazard by conditioning their employees' remuneration to signals of their effort (e.g. the amount of man-hours in the workplace). In equilibrium, firms will be willing to offer incentive pay when its marginal cost is outweighed by the increase in expected revenue, the latter related to a reduced sick wage bill associated with less employee absence. Similarly, workers will be incentivized to improve their attendance behavior when the marginal gain from not being absent exceeds the marginal cost of effort. This will be determined by the difference between the utility of the overall wage (base salary and bonus pay), on the one hand, and the sum of reservation utility and sick pay, on the other.

Since bonus pay is typically not covered (or partly covered) by the sickness insurance arrangements of firms (Barmby et al. 1991), the shadow price of absence is attenuated by the offer of incentive pay. Furthermore, it has been illustrated that diligent or healthier employees will self-select into firms offering PRP (Lazear 1986, 2000). Due to the greater effort and/or specific traits of those receiving incentive pay, a positive relationship between PRP earnings/productivity and employment has been documented (Seiler 1984; Booth and Frank 1999; Gielen et al. 2010). The gap between contractual and actual hours should therefore be bridged as workers respond optimally to the higher opportunity cost of leisure entailed by PRP. In addition, PRP schemes constitute part of a bundle of managerial innovations, known as High Performance Workplace Practices (HPWPs) (Bloom and van Reenen 2010). Since HPWPs are believed 
to breed greater feelings of employee empowerment and job satisfaction (Bauer 2004), absenteeism is also expected to be negatively related to PRP via this avenue.

Despite the above arguments, the provision of PRP is likely to result in greater absence for a number of reasons. PRP schemes may undermine valuable teamwork by fostering an individualistic organizational culture that is permeated by envy and free-riding (Holmström 1979; Milgrom and Roberts 1992). Moreover, high-powered PRP schemes are believed to heighten the power asymmetry between supervisors and the workforce (Kohn 1993). Psychological concerns over a potential "crowding-out" of intrinsic motivation and morale have been raised, with assumed adverse effects on productivity and turnout at work (Frey 1993; Frey and Jegen 2001). PRP has also been associated with adverse health outcomes, such as dissatisfaction with work-related stress (Pouliakas and Theodossiou 2009), an increased incidence of workplace injuries (Freeman and Kleiner 2005; Bender et al. 2009) and "presenteeism" (Chatterji and Tilley 2002; Skatun 2003). The latter refers to a greater likelihood of workers becoming chronically ill due to pressure to return back to work earlier than what is required for a healthy recovery. Furthermore, inadequacies in compensation design have been highlighted, such as time inconsistency problems when offering long-term incentives to temporary contract employees (Schnebller and Kopelman 1983) and perverse reactions to capped bonuses that are stretched over extended qualifying time periods. For instance, workers are found to 'backload' their absence days towards periods in which they anticipate to have already met their targets (Frick et al. 2008).

From the conflicting hypotheses outlined above it becomes evident that there is no theoretical consensus regarding the overall effect of PRP on absenteeism. This ambiguity is also mirrored in the empirical evidence, with some studies confirming the beneficial impact of financial rewards on absence rates (e.g. Jacobson 1989; Hassink and Koning 2005; Dale-Olsen 2009), while others finding nonmeasurable effects (Engellandt and Riphahn 2011). 


\section{Data Sources}

Our data are mainly derived from the 1998 and 2004 Cross-Sections of the Workplace Employment Relations Survey (WERS). Also, a merged subsample of the 2004 WERS data with the Annual Survey of Hours and Earnings (ASHE), and the 1998-2004 WERS Panel Survey are utilized. ${ }^{4}$ As in Heywood et al. (2008), only private sector establishments are retained for the purpose of the empirical analysis. ${ }^{5}$ In addition, firms that offer PRP solely to managerial employees are dropped from the analysis, since nonmanagerial workers and executives are likely to be faced with a completely different set of incentive compatibility constraints (Murphy 1999). ${ }^{6}$ In addition, some of the PRP questions in the WERS survey are asked only if non-managerial workers are eligible for the respective instruments.

\subsection{The WERS Cross-Section Data}

The 1998 and 2004 cross-sections are the fourth and fifth instalments of a Government funded series of surveys conducted at British workplaces. The previous surveys were conducted in 1980, 1984 and 1990. The sample of workplaces was randomly drawn from the Interdepartmental Business Register (IDBR). This is maintained by the Office for National Statistics (ONS) and is considered to be the highest quality sampling frame of workplaces available in the United Kingdom. The sample is stratified by workplace size and industry and larger workplaces and some industries are overrepresented (Chaplin et al. 2005). An establishment is defined as comprising the activities of a single employer at a single set of premises,

\footnotetext{
${ }^{4}$ The non-publicly available ASHE-WERS dataset was accessed via the Virtual Micro-data Laboratory (VML) of the Office for National Statistics (ONS) in Glasgow. This dataset allowed us to identify establishments that are part of the same organization in the 2004 WERS cross section data, on the basis of confidential enterprise reference numbers. This permitted the estimation of absence regressions that control for "organization fixed effects", as described in sub-section 5.1 below.

${ }^{5}$ The relative inefficiency of explicit incentives in the public sector is typically attributed to the more complicated nature of performance measurement in state-level jobs, the prevalence of multiple principals, the crucial role of teamwork in public goods production and the important sorting effects due to public service motivation (Dixit 2002; Burgess and Rato 2003; Prendergast 2008; Marsden 2009). Indeed, the empirical analysis confirmed the absence of any significant PRP effect on worker attendance in the public sector establishments of the WERS data (available upon request).

${ }^{6}$ In order to ensure that the empirical estimates are not affected by the greater prevalence of variable pay schemes in financial services relative to other sectors, sensitivity tests have also been undertaken that exclude the financial sector from the sample. The main results of the paper hold.
} 
for instance, a single branch of a bank, a car factory, or a school. The survey comprises three main sections; the 'Management Questionnaire' (MQ) (face-to-face interviews with the most senior manager with day-to-day responsibility for personnel matters), the 'Worker Representative Questionnaire' and the 'Employee Questionnaire'. All three interview based questionnaires were conducted using ComputerAssisted Personal Interview (CAPI).

We use data from the MQ as information on absence rates is only available in this part of the survey. ${ }^{7}$ Nonetheless, the matched employer-employee element of the data is exploited for the purpose of robustness checks. The 1998 (2004) sample comprises of 2,173 (2,006) establishments, which, after retaining private sector establishments that extend the offer of PRP to the non-managerial workforce, is reduced to $1,192(1,281) .{ }^{8}$ Due to the stratified nature of the survey, the estimates are weighted in order to be representative of the sampling population.

The MQ collected data from managers about the pattern of employee non-attendance in the workplace. The exact question was phrased: "Over the past 12 months what percentage of work days was lost through employee sickness or absence at this establishment? Please exclude authorized leave or absence, employees away on secondment or courses, or days lost through industrial action". 9 This question captures mainly unplanned absence such as casual sick days as well as absence due to employees not turning up to work for some other reason.

\footnotetext{
${ }^{7}$ The survey population for the MQ is all British workplaces barring those in agriculture, hunting and forestry, fishing, mining and quarrying, private households with employed persons and extra-territorial organizations.

${ }^{8}$ The response rate in the 1998 (2004) MQ was 80\% (64\%). Changes in the nature of interest in employment relations led to substantial redesign of the 2004 wave. A major modification was the incorporation of small workplaces (i.e. those employing between 5 and 9 employees). There were also a number of changes to the format of the various survey questions (Airey et al. 1999; Kersley et al. 2006).

${ }^{9}$ It is acknowledged that this definition of absenteeism does not clarify what constitutes "authorized" leave, and that the definition of "authorized" leave may differ across workplaces. Nonetheless, it is believed to be a reliable measure of absence, since managers who responded to the survey were posted an Employee Profile Questionnaire (EPQ) and were requested to have it ready prior to the interview. This interviewing strategy gave managers the opportunity to report the establishment absence rate on the basis of their official registers rather than solely by memory. Thus, it is expected that recall bias is minimized relative to other sources that have used employee reports on absenteeism. The latter have typically been fraught with measurement errors due to the tendency of employees to underreport absence or to count days not scheduled for work as part of their overall absenteeism (Barham and Leonard 2002).
} 
Among workplaces where managers were able to provide an $\operatorname{answer}^{10}$, the average rate of absenteeism in the 1998 (2004) samples equates to an average loss of 4.3 (4.6) percent of working days per establishment. ${ }^{11}$ Panels A (1998) and B (2004) of Figure 1 present the distribution of the absence rate across workplaces. It is evident that there is significant variation of absence rates across establishments in both years. Almost all workplaces reported some degree of absenteeism. Those in the lower decile have a mean absence rate of 1 percent or below in both waves, while managers in establishments in the highest decile reported that at least 8 percent (10 percent) of their workforce was absent at any given day in 1998 (2004). Zero absence rates account for only 2.1 percent (4.4 percent) of the non-missing observations in the 1998 (2004) sample, so there is no excess concentration of responses at the left tail of the distribution. In addition, both distributions are skewed to the right, so the median is lower than the mean. For instance, in the 1998 (2004) sample the median is 3.43 (3.0).

\section{[INSERT FIGURE 1 HERE]}

Managers were also asked questions regarding the provision of different forms of variable pay schemes in their workplace. Table A1 in the Appendix provides detailed definitions for the contingent pay variables of interest in the survey. Importantly, the PRP options were specified differently between the 1998 and 2004 waves. Nevertheless, in order to retain consistency in the PRP categories, the following four groups of contingent pay have been constructed following Pendleton et al. (2009); (i) Individual-based PRP: This is broken down into two constituent parts that include an objective and a subjective component, namely individual payment by results (IPBR) and merit pay (MP). The former is

\footnotetext{
${ }^{10}$ The percentage of missing absence responses in the raw data was 18.5 in 1998 and 17.3 in 2004. It was confirmed that there is no systematic bias in the pattern of non-response using a Heckman-type selection model. The identifying variable used is whether firms keep records of their total costs, since this is also expected to be associated with their propensity to keep records on absence, but is not necessarily related to the level of absence. In addition, sensitivity tests (upon request) confirm the robustness of the results after dropping outlier observations (e.g. firms with absence rates higher than 20 percent).

${ }^{11}$ Using individual level data from the UK Labour Force Survey (LFS), Ercolani (2006) finds a mean absence rate of 3.19 for 1998 and 2.93 for 2004, respectively. The lower estimates may be due to employee recall bias, or to the fact that the author constructs absence rates by identifying differences between actual and usual hours of work per week that are attributed solely to sickness or injury. The WERS definition, instead, captures a more broad measure of absence.
} 
defined as PRP offered on the basis of measurement of an employee's individual performance or output, whereas the latter captures the subjective evaluation of individual performance by a supervisor or manager (McLeod and Malcomson, 2000); (ii) collective payment by results (CPBR): This refers to PRP determined according to group, workplace or organization-based measures of performance or output; (iii) profit-related payments or bonuses (PFRP); and (iv) employee share ownership schemes (ESO) (e.g. share incentive plans, save as you earn, company share options). ${ }^{12}$

It is clear from Table 1 (Panel A) that a relatively large number of firms offer PRP of various types in the two waves. ${ }^{13}$ About 11-12 percent of workplaces have IPBR and CPBR schemes in place in 1998, while around $40 \%$ utilize PFRP. The incidence of ESO is stable at $18 \%$ in both waves. MP is offered by a non-trivial proportion of workplaces (15 percent) in 2004, while there is also a substantial incidence of IPBR (21 percent) and CPBR (24 percent) schemes in that year.

[INSERT TABLE 1 HERE]

\subsection{The ASHE-WERS Data}

The WERS MQ collects limited information on wages. Even when using the data provided by the Employee Questionnaire, details on hourly and weekly wages are only provided within banded categories. Furthermore, no information is provided in the WERS cross-section data indicating the proportion of employees' pay that is linked to performance measures. In order to overcome these deficiencies, the merged ASHE-WERS dataset has been utilized. This is constructed by combining information on individuals contained within the 2004 ASHE with workplace variables collected from the WERS 2004 MQ. The ASHE has taken place since 2004 and contains data on a 1\% sample of British employees,

\footnotetext{
${ }^{12}$ In the 1998 questionnaire there was also an additional option offered to the respondents, which was referred to as "other cash bonuses" (OCB). Due to the vague nature of this category, it has been included as a separate variable in the 1998 absence regression. The variable MP has also been constructed on the basis of different survey questions between the 1998 and 2004 waves. In particular, MP was not explicitly defined as part of a variable pay scheme in 1998, whereas it was in the 2004 wave.

${ }^{13}$ In general, it has been noted that the PRP data show a substantial fall in incidence in the 1998 wave. This is believed to be associated with the substantial revamping of the PRP questions in that survey (Pendleton et al. 2009). More accurate conclusions regarding the trends in variable pay schemes over the years can thus be drawn by examination of the 1998-2004 WERS Panel Survey, since equivalent definitions have been used.
} 
randomly selected on the basis of the last two digits of their national insurance numbers. It is possible to merge the WERS and ASHE datasets on the basis of a combination of enterprise reference numbers and workplace postcodes (Davies and Welpton 2004). After merging the two datasets, 5,922 individuals remain from 785 matched workplaces, 3,248 (55 percent) of which are employed in 393 private sector establishments. This sample is characterized by a greater prevalence of workers who are employed in larger workplaces and in certain industries (such as utilities and manufacturing), and is therefore not representative of British establishments as is the original WERS sampling frame. To ensure that the empirical analysis based on this subsample is not biased relative to the original 2004 WERS cross-section design, an appropriate weighting procedure has thus been utilized following Davies and Welpton $(2004) .^{14}$

The ASHE contains information on employees' working hours and earnings obtained by administrative employer records, thus providing accurate measures. It also permits identification of the component of employees' gross annual earnings that is tied to an overall measure of bonus or incentive payments (including profit sharing, productivity performance, bonuses, piecework and commission payments). Almost $20 \%(n=1,137)$ of the individuals in the sample are recipients of some form of incentive pay, corresponding to a median of 6 percent (£1000) of their annual gross pay. When averaged across establishments, it is evident that about 42 percent of workplaces offer some form of contingent pay scheme (i.e. there is at least one employee within a firm whose remuneration contains elements of incentive pay). As seen in Table 1 (Panel B), the average proportion of incentive pay tied to earnings within those firms that have adopted performance-contingent pay schemes is approximately 4 percent.

${ }^{14}$ This is based on a logistic regression that predicts the probability that the WERS workplaces have matching ASHE records on the basis of firm size, industrial groups, proportion of occupational shares, distribution of earnings groups and incidence of PRP schemes. The inverse of the predicted values are subsequently used as weights in the absence regressions. Once the above weighting procedure is implemented, comparable estimates are obtained between the WERS-ASHE subsample and the original 2004 WERS data. Estimates are available upon request. 


\subsection{The 1998-2004 WERS Panel Survey Data}

The 1998-2004 Panel Survey returned to a random selection of the 2,191 workplaces that participated in the 1998 Cross-Section, with the purpose of investigating the changes that had taken place in those workplaces over the preceding six years. Some 1,479 workplaces from the 1998 cross-section were selected to be traced for re-interview in 2004 , though 1,247 were classified as continuing workplaces. The survey, with a response rate of 77 per cent, yielded an achieved sample of 956 continuing establishments. Unfortunately, no information on absence rates was collected in the 2004 wave. Thus, formal panel data techniques cannot be employed. Nevertheless, the panel survey allows for the identification of the relationship between the absence rate and PRP status of firms in 1998, with the probability that the same firms employed PRP schemes in 2004. This information is used in order to draw inferences about the causal nature of the effect of PRP on absenteeism and the existence of any dynamic interactions between absenteeism and PRP.

An investigation of the dynamic correlations in the raw data reveals that a significant proportion (86\%) of firms that had PRP schemes in 1998 continued to use variable remuneration in 2004. Importantly, 47\% of firms that did not employ any form of contingent pay in 1998 are observed to do so six years later. Table 1 (Panel C) also indicates an increasing proportion of firms using MP ${ }^{15}$, IPBR and CPBR schemes over time, while there was a slight decrease in the use of more aggregate PFRP and ESOtype incentives. Furthermore, significant correlation coefficients $(r)$ can be observed in Panel C between the absence rate of firms in 1998 and the incidence of variable pay in the same firms in 1998 (negative correlation) and 2004 (positive correlation) suggesting that firms with high absence rate in the past were more likely to adopt PRP schemes in the future. ${ }^{16}$

\footnotetext{
${ }^{15}$ Millward et al. (1992), using data from previous WERS surveys (1980, 1984 and 1990) and analyzing workplaces with 25 or more employees, find that the fraction of workers who received some kind of merit pay was $34 \%$ in 1990 . ${ }^{16}$ In particular, for firms that did not have any type of PRP in 1998 the Pearson correlation coefficient between the 1998 absence rate and IPBR schemes in 2004 is $r=0.30(p=0.01)$, while for MP schemes it is $r=0.35(p<0.01)$.
} 


\section{Effect of PRP on Absence Rates}

\subsection{Descriptive statistics of the PRP-absenteeism relationship}

Table 2 provides some simple cross-tabulations of the raw data on absence and various types of incentive pay. An independent samples t-test confirms that only MP is associated with significantly lower absence rates in both waves, though IPBR, CPBR and other cash bonuses (OCB) are also conducive to higher workplace attendance rates in the 1998 sample. These results highlight the important discrepancies that arise with respect to the distinct impact of different PRP instruments on absenteeism.

\section{[INSERT TABLE 2 HERE]}

\subsection{Effect of incidence and coverage of PRP schemes on absence}

In order to detect the ceteris paribus relation between financial incentives and the absence rate, a number of important determinants of absenteeism are taken into account. As identified in the relevant literature (e.g. Heywood et al. 2008), these include variables describing the demographic composition of the workforce (e.g. proportion of employees by gender and age), firm identity (establishment size, region of operation) and the nature of production (e.g. industrial sector, shares of occupational groups). Firm characteristics that are related to the labour-leisure tradeoff are also taken into account, such as working time schedules (e.g. mean establishment hours of work, whether employees engage in shift work, entitlement to an annualized hours scheme), contractual flexibility (proportion of employees on fixed term and part-time contracts) and economic incentives (mean establishment earnings, unemployment rate by travel to work area). Furthermore, the context of industrial relations (trade union density, presence of joint consultative committees and quality circles) and occupational health and safety policies (provision of sick pay in excess of statutory requirements, health and safety committees) are included as controls. Summary statistics of all explanatory variables of interest are presented in Table A2 in the Appendix.

We estimate the following equation using Ordinary Least Squares (OLS) :

$$
\text { Absence }_{j}=\beta_{0}+\beta_{1} P R P_{j}+\beta_{2} W_{j}+\beta_{3} I_{j}+\beta_{4} R_{j}+\varepsilon_{j}
$$


The dependent variable Absence $_{j}$ indicates the absence rate of establishment $j$, where $j=1, \ldots, N, P R P_{j}=$ \{IBPR, MP, CPRB, PFRP, ESO, OCB $\}$ captures the offer of various PRP schemes within establishments, $W_{j}$ summarizes workplace characteristics, $I_{j}$ captures industry fixed effects, $R_{j}$ stands for region fixed effects and $\varepsilon_{j}$ is the establishment-specific error term. OLS coefficients of the effect of PRP on Absence will be unbiased provided that $E\left(\varepsilon_{j} \mid P R P_{j}\right)=0$. OLS may nevertheless be inappropriate given that Absence $_{j}$ is a fractional response variable, in which case Papke and Wooldridge (1996) suggest that a logistic model may be more suitable. However, as no significant differences are detected between the estimates of logistic and OLS models in the analysis, the discussion in the remainder of the paper presents the OLS coefficients for simplicity. ${ }^{17}$

Panel A of Table 3 presents estimates of the various PRP schemes on the absenteeism of private sector establishments in Britain for both years of data. ${ }^{18}$ It is evident that variable pay schemes that reward individual merit on the basis of subjective appraisals have a significant negative effect on the mean absence rate in both waves. IPBR also has a significant inverse relation to absence in 1998. Specifically, firms which utilize MP and IPBR have a one percentage point lower absence rate in the 1998 data compared to firms without such schemes, ceteris paribus. For a mean absence rate of 4.3 percent (sample absence mean in 1998), the true effect is equal to -23.3 percentage points [(-1.0/4.3)*100], which is a considerable effect. A significant negative effect on absenteeism of 0.8 percentage points is also found with respect to the provision of OCB by firms (i.e. an 18.6 percentage point decrease at the mean). In contrast, there is no evidence of a significant link between absence, CPBR, PFRP and ESO.

\footnotetext{
${ }^{17}$ A generalized linear model (GLM) was also estimated, which assumes that the logit transformation of Absence comes from the family of binomial distributions. This takes into account excess concentration of observations at the boundaries of the permissible interval of responses. The marginal effects and their associated standard errors obtained from the GLM were almost identical to the OLS results reported in Table A3 (GLM results upon request).

${ }^{18}$ The regression coefficients of the remaining explanatory variables are found to correspond in most cases with the predictions of prior literature. Due to space considerations they are not discussed in the main text but are available in Table A3 in the Appendix.
} 
Column 2 of Table 3 presents similar results for the 2004 wave. The regression coefficient of MP suggests that establishments that adjust their employees' compensation by subjectively evaluating their performance have a lower number of lost workdays compared to those that do not (by 0.8 percentage points). For a mean absence rate of 4.6 percent (sample absence mean in 2004), this translates to a decrease of 17.4 percentage points in the mean absence rate $[(-0.8 / 4.6) * 100)]$. As before, no evidence of a significant relationship between collective or aggregate forms of PRP (CPBR, PRRP, ESO) and absenteeism is found. Importantly, the significant negative coefficient of IPBR in the 1998 data is no longer present in 2004. This could potentially be related to the substantial alteration in the definition of the variable in the 2004 survey, which explicitly identified the components that comprise the categories "payment by results" and "merit pay".

The WERS data permits further investigation of the impact of the coverage of PRP schemes on absenteeism. Specifically, managers that replied affirmatively to whether their establishment offers individual or collective PRP were subsequently asked to reply to the question: "What proportion of nonmanagerial employees at this workplace have received performance related pay in the last 12 months?"19 Managers' responses have been grouped into four broad categories: "1-39\%", "40-79\%" and "80-100\%", the omitted category being "None". The results of an estimated absence equation that includes variables describing the proportion of workers covered by PRP, instead of its incidence, are displayed in Table 3 (Panel B). The regression coefficients are indicative of the fact that firms with a more extensive coverage of PRP are more likely to experience lower absence rates. ${ }^{20}$

\section{[INSERT TABLE 3 HERE]}

\footnotetext{
${ }^{19}$ Managers had to choose between the following categories: 1 "All" (100\%), 2 "Almost all" (80-99\%), 3 "Most" (60-79\%), 4 "Around half" (40-59\%), 5 "Some" (20-39\%), 6 "Just a few" (1-19\%), 7 "None".

20 Following Pendleton et al. (2009), the possibility that establishments utilize different configurations of PRP schemes has also been examined. We did this by regressing the number (counts) of simultaneous PRP schemes used by establishments (e.g. $0,1, \ldots, 5)$ on the absence rate. However, significant evidence in favor of multiple interaction effects is found only in the 1998 data (upon request).
} 


\subsection{Effect of proportion of PRP tied to earnings: ASHE-WERS data}

As mentioned in sub-section 3.3, the ASHE-WERS dataset allows for identification of the portion of employees' annual gross earnings that comes from bonus or incentive payments (profit sharing, productivity performance, piecework and commission), although it is not possible to distinguish the latter into its respective components. On the basis of this data set, the proportion of employees' salaries that is linked to a general measure of incentive pay, henceforth referred to as "intensity of PRP", is calculated for the year 2004. The average intensity of PRP per workplace is subsequently computed using the matched employer-employee records.

Using a similar specification as in the 2004 WERS cross section data, equation 1 has been reestimated on the matched ASHE-WERS subsample, albeit with the addition of the PRP intensity variable and a reliable measure of mean hourly earnings per establishment as separate explanatory variables. The incidence of the various types of incentive schemes provided by firms (e.g. MP, IPBR, CPBR, PRRP, ESO) and all other important determinants of absenteeism (as in Table A3) are controlled for in the regression, whilst the standard errors are adjusted for clustering of employees within the same workplace. In this manner, Panel $\mathrm{C}$ of Table 3 indicates that there is a statistically significant negative relationship between the intensity of PRP and absenteeism, ceteris paribus. ${ }^{21}$ In particular, a 1 percentage point increase in the average intensity of PRP per establishment is found to be associated with a 14 percentage point decrease on mean absence. This result closely resembles those of Gneezy and Rustichini (2000) and Pouliakas (2010) who have shown that a higher intensity of incentive pay is associated with greater job satisfaction and intrinsic motivation among employees.

\footnotetext{
${ }^{21}$ An alternative yet more arbitrary specification has also been utilized, whereby the continuous PRP intensity variable has been separated into a number of indicator dummies (e.g. 0\%, 1-4\%, 4-10\%, >10\%), roughly corresponding to the frequency distribution of the variable. It is hence confirmed that firms that employ highpowered incentives are significantly more likely to benefit from a lower absence rate relative to those firms that do not employ PRP schemes.
} 


\section{Sensitivity Analysis}

\subsection{Controlling for organization fixed effects}

In the WERS data a number of workplaces constitute units of the same organization. To the extent that there is random variation in the use of particular PRP schemes by individual local branches that form part of a larger enterprise, the influence of PRP on absenteeism can hence be explored within a more "controlled" setting. In particular, identification of the exact workplaces that fall under the umbrella of the same organization permits the examination of the within-organization influence of PRP schemes on absenteeism that purges a significant part of any unobserved heterogeneity affecting OLS estimates. In order to pursue this avenue further, the unique IDBR reference numbers of firms contained with the ONS's Virtual Micro-data Laboratory (VML) have been consulted. Cases in which at least two establishments (workplaces) of the WERS sample are local units of the same enterprise (organization) have been identified and retained. This led to a subsample of 305 workplaces that constitute local units of 97 broad organizations, whereby each enterprise contains an average of 3.14 workplaces. After confirming that there is significant within-organization variation in the incidence of incentive pay arrangements and in the absence rate ${ }^{22}$, the main absence equation (1) has been modified as follows:

$$
\text { Absence }_{j o}=\beta_{0}+\beta_{1} P R P_{j o}+\beta_{2} W_{j o}+\beta_{3} I_{j o}+\beta_{4} R_{j o}+\eta_{o}+\varepsilon_{j o}
$$

where the subscript 'o' now stands for 'organization' and $\eta_{\mathrm{o}}$ is the organization fixed effects term, capturing all of the factors that are constant across different workplaces that belong to the same organization. A fixed effects estimator has therefore been used to estimate equation (2) using the subsample of the 2004 WERS data described above. The main specification (eq. 1) has been retained, albeit with the omission of industry fixed effects since all firms within the same organization belong to the same industry. Importantly, Column 1 of Table 4 shows that the negative influence of MP on

22 For example, the overall variation of MP schemes in the 2004 data is 0.475 , the between-organization variation is 0.339 and the within-organization variation is 0.367 . Similarly, the overall variability of the absence rate is 0.079 , the between-organization variation is 0.047 and the variation between establishments of the same organization is 0.064. The figures for the remaining variable pay schemes are available upon request. 
absenteeism persists even after controlling for a number of organization-invariant characteristics (e.g. the managerial policies of the headquarters). This finding supports the robustness of the OLS estimates reported in section 4 .

\section{[INSERT TABLE 4 HERE]}

\subsection{Controlling for earnings and hours of work}

As predicted by the standard labour-leisure paradigm, reliable estimation of an absence equation hinges critically on correctly identifying variation in earnings and working hours. For this reason, significant attention has been paid to ensuring that the PRP coefficients are robust to the inclusion of alternative measures of earnings and hours in the absence equation. First, the estimation has been replicated by including as controls relevant variables from the WERS cross-sectional surveys, such as the share of employees within earnings bands and the average work-week or overtime hours per establishment. Reassuringly, the significant estimates of the PRP variables reported in Table 3 (Panel A) hold (available upon request).

Furthermore, given that the ASHE dataset contains superior information on working hours and earnings that come from administrative sources, the main 2004 absence regression has been replicated on the merged ASHE-WERS subsample. A constructed measure of average gross hourly earnings per establishment has been included as an additional regressor. As can be seen from Table 3 (Column 1 of Panel C), workplaces that offer a higher level of pay per hour to their employees are found to have a significantly lower rate of absence in the order of 7.6 percentage points. Importantly, the statistically significant negative effect of MP on absenteeism persists even after the inclusion of this accurate hourly earnings measure.

\subsection{Taking self-selection into account}

As is well-known from the model of Lazear (1986), the prospect of PRP is likely to give rise to a selection issue, whereby more able, diligent and perhaps healthier employees are attracted to such 
compensation mechanisms. Therefore, it is typically difficult to disentangle whether PRP affects particular outcomes, such as absenteeism, due to its incentive properties or because of self-selection of different types of workers. In order to test whether the negative effect of individual PRP schemes on absenteeism is robust to the selectivity process, a number of additional control variables have been utilized in the analysis. These are used as proxies of the relative churning and "quality" of the workforce within establishments. First, a new variable has been included in the specification that captures the extent to which the workforce has remained the "same" in an establishment during the previous year of the survey. This is constructed after taking into account the proportion of new entrants into the workplace, minus those that left for a specific reason (e.g. dismissed, voluntary resigned, redundant and retired). Although this measure is likely to underestimate the full impact of the selection process, it is notable that the negative relationship of the individual PRP variables with absenteeism persists even after taking the variation in the composition of the workforce between establishments into account (see Column 2 of Table 4). Furthermore, an additional test has been undertaken by controlling for whether firms use performance/competency or personality/attitude tests during the recruitment process. As before, the MP and IPBR coefficients remain robust (results upon request).

\subsection{Controlling for the incidence of workplace illnesses and injuries}

According to Bender et al. (2009), even though piece rates are associated with greater productivity and a positive wage premium, they entail a greater likelihood of workplace injury occurring after controlling for other workplace hazards. Another counterproductive influence of PRP includes the so-called "presenteeism" phenomenon. Such a process is likely to result in a greater chance of future absence spells (Böckerman and Laukkanen 2010). In order to take the above issues into account two additional regressors have been added to the specification, which capture the workplace injury and illness rate. Specifically, they measure the proportion of employees that have sustained certain types of injuries (e.g. bone fracture, amputation, loss of sight etc.) or illnesses/disabilities/other physical problems (e.g. skin or respiration problems, stress, musculoskeletal disorders) during working hours in the previous year of the 
survey. Since the original dependent variable refers to the percentage of workdays lost through both employee sickness or absence, we believe that by controlling for the illness or injury rate one can draw inferences regarding the effect of PRP on the residual component of absence. This residual part of absenteeism should be independent of the state of health and safety of the workforce. Indeed, as shown in Column 3 of Table 4, even after engaging in such an exercise the beneficial attendance effect of MP and IPBR remains unaltered.

\subsection{Interaction with teamwork}

While the effectiveness of compensation schemes that rely heavily on teamwork hinges critically on the 'silent' constraining effect of peer pressure (Kandel and Lazear 1992), the evidence of Frick et al. (2008) and Dale-Olsen (2009) suggests that teamwork may be combined with PRP to significantly raise absence rates. This is attributed to the fact that since team production units can cover for absent colleagues without undue disruption in output, workers who anticipate meeting their production targets are likely to free-ride by taking unauthorized absence. It is therefore of interest to examine closely the interrelationship between teamwork, the provision of performance pay and absenteeism. In fact, the positive interaction term (Column 4 of Table 4 ) suggests that the sensitivity of absence to PRP is muted in firms with interdependent production. ${ }^{23}$ This finding is in line with Brenčič and Norris (2010) and suggests that firms that are dependent on the productive collaborations of workers should exercise caution when deciding whether to implement a PRP scheme as part of a worker attendance plan.

\subsection{Controlling for job satisfaction}

In order to examine whether the negative effect of individual PRP on absenteeism is confounded by the job satisfaction of employees, the mean job satisfaction with respect to the facets of pay, influence and

\footnotetext{
${ }^{23}$ It is acknowledged that this effect may be reflecting the endogenous nature of the relationship between PRP and teamwork. Nonetheless, neither it is not possible to decouple the effects of these two variables within the individual cross-sectional datasets, nor to use the panel element of the survey since we do not observe absence in the 2004 wave.
} 
achievement has been computed for each workplace, after matching information obtained by the WERS Employee Questionnaire. ${ }^{24}$ Table 4 (Column 5) illustrates that the significant effect of MP on absenteeism disappears in both waves once the job satisfaction variables are entered into the absence regressions as separate explanatory variables. Job satisfaction with pay, in particular, has a significant negative association with absenteeism. This suggests that the effect of MP on attendance conduct hinges critically on whether the appraisal process that is linked to wage-setting provokes feelings of satisfaction among employees with respect to their compensation.

\subsection{Quintile regressions}

While the OLS estimates of Table 3 show that individual-based PRP schemes are likely to have a negative effect on absenteeism at the mean of the sample, it is interesting to explore the heterogeneity in the coefficients further due to the skewed nature of absenteeism across establishments. On theoretical grounds one would expect that variable pay schemes will exert a dissimilar impact on absenteeism, depending on whether firms have much higher or lower absence rates relative to a mean level of absence. Most firms should be able to tolerate a mean level of absenteeism without experiencing production difficulties. However, levels of absence that exceed this sustainable level may be detrimental to firm performance due to difficulties in carrying out regular productive activities. In contrast, levels that are below the sustainable rate may give rise to problems such as presenteeism, or undue pressure on workers seeking to strike a work-life compromise.

Table 5, therefore, contains estimates of quintile regressions that examine the relationship between PRP schemes and absenteeism at five segments of the absence distribution. It is evident that the above $a$ priori hypothesis is confirmed, since one observes an asymmetric effect of PRP schemes on absenteeism. In particular, it is found that the marginal impact of PRP on the absence rate is larger at the higher rungs

\footnotetext{
${ }^{24}$ These are the only three job satisfaction facets that are the same in the two WERS waves.
} 
of the absence distribution relative to the lower quintiles. This finding is presumably indicative of the greater potential that contingent pay might have for lowering the absence rate of firms experiencing high levels of absenteeism as they return back to the sustainable rate over time. In contrast, the strength of the effect of PRP is likely to be muted in establishments that have absence rates that are close to some average level.

\section{[INSERT TABLE 5 HERE]}

\section{Endogeneity of PRP and Absence}

Despite the robustness of the negative MP and IPBR (only in 1998) coefficients in the absence regression, it is possible that endogeneity and reverse causation underlie the significant correlations of the variables. An important criticism regarding the detection of the 'causal' effect of PRP on firm performance is that cross-sectional estimates are likely to mask unobserved firm heterogeneity. This may include dynamic feedback effects of past absence rates and inherent differences in the trend of productivity, both of which are correlated with the introduction of PRP schemes by firms and with current absence rates. For instance, it is possible that lower present absence rates may be unrelated to the effect of PRP per se, and reflect, instead, a historically rising trend of productivity that is correlated with the adoption of costly variable pay policies in the first place (Prendergast 1999, p. 43). Previously abnormal absence rates that are regressing to the mean may also coincide with the implementation of PRP schemes by specific firms.

In order to address the aforementioned concerns, extra controls capturing the managers' subjective evaluation of current labour productivity within the establishment have been considered (see Column 6 of Table 4). In addition, the 1998 dataset contains the managers' subjective evaluation of whether labour productivity in their establishment has gone up or down compared to five years ago. In all cases no evidence is found that would imply that the effect of PRP on absenteeism is somehow modified by the fact that firm productivity or its trend is likely to be correlated with both the adoption of PRP schemes and lower absence rates. 
Furthermore, the 1998-2004 WERS Panel Survey has been utilized in order to explore the potential interrelationship between past absence rates of firms and the likelihood that the same firms have employed particular types of PRP schemes in future time periods. In particular, the following equation has been estimated using a probit estimator:

$$
P R P_{04 j}^{i}=\beta_{0}+\beta_{1} \text { Absence }_{98 j}+\beta_{2} P R P_{04 j}^{l}+\beta_{3} P R P_{98 j}+\beta_{4} X_{04 j}+\beta_{5} X_{98 j}+\beta_{6} \Delta_{04-98 j}+u_{j}
$$

where the probability that firms $(j=1, \ldots, N)$ are observed to have specific PRP schemes in $2004\{i=$ MP, IPBR, CPBR, PRRP, ESO, OCB $\}$ is regressed against the rate of absence that prevailed in 1998 (Absence ${ }_{98}$ ). To obtain an unbiased estimate of $\beta_{1}$ a number of important confounding factors are taken into account, including the incidence of the remaining forms of PRP in the same year $\left(P R P_{04}^{l}\right)$, the historical incidence of PRP in $1998\left(P R P_{98}\right)$, current and past establishment characteristics $\left(X_{04}\right.$ and $\left.X_{98}\right)$ and variables capturing the historical evolution of the firms' financial performance and of managementemployee relations since $1998\left(\Delta_{04-98}\right)$.

Results from equation (3) are displayed in Table 6A, which includes the marginal effects of the absence and PRP variables of interest. ${ }^{25}$ The results indicate that higher levels of past absence are only significantly related to the incidence of individual-based PRP (MP and IPBR) in $2004 .{ }^{26}$ In Table 6B it is also shown that this positive effect persists even among those firms that did not have those particular PRP schemes six years earlier. Therefore, there is evidence confirming the existence of an important endogenous feedback mechanism between absenteeism and PRP, whereby high absence rates in the past induce the introduction of PRP schemes within establishments in future time periods. This highlights the

\footnotetext{
${ }^{25}$ The estimates of the remaining control variables are available upon request. Appropriate panel weights are used in the estimation of equation (3).

${ }^{26}$ We also ran an OLS (reverse) regression where we regressed absence in 1998 on PRP schemes in 1998 and 2004 , and all the other controls used in equation 3. We found a positive and statistically significant relationship between absence in 1998 and merit pay in 2004, which confirms the results presented in Table 6A (results upon request).
} 
fact that not including lagged values of absence in the main empirical specification of equation (1) is likely to have resulted in underestimation of the true effect of PRP on current rates of absenteeism. ${ }^{27}$

\section{[INSERT TABLES 6A AND 6B HERE]}

\section{Conclusion}

Using two cross-sections (1998 and 2004) of the WERS, the matched employer-employee ASHE-WERS dataset and the panel element of the 1998-2004 WERS, the effect of various types of incentive pay on the absence rates of private sector firms is examined. Incentives that are tied to individual performance or output, particularly those that are tightly linked to the subjective evaluation of individual merit, are found to be significantly related to lower absenteeism, ceteris paribus. This effect is stronger in firms that cover a greater proportion of their non-managerial workforce with contingent pay policies. A series of sensitivity tests confirm that the negative relation of PRP with absence is robust to selectivity and to the inclusion of administrative measures of earnings and working hours, organization fixed effects and the injury and illness rate of establishments. However, job satisfaction with pay appears to be an important factor that can mediate the positive impact of MP schemes on attendance. High-powered incentives that link a greater share of employee earnings to incentive pay are also found to exert a significant negative influence on absenteeism. Quintile regression results suggest that PRP has an asymmetric effect on absence. We find that PRP has a stronger effect at establishments that have an absence rate above a sustainable level. Moreover, evidence from the 1998-2004 WERS Panel survey indicates that an endogenous feedback mechanism is at work, whereby high past absenteeism is related to a greater future incidence of individual PRP in firms, which, in turn, is correlated with lower current rates of absence.

\footnotetext{
${ }^{27}$ It is known by the formula for omitted variable bias that $E\left(\hat{\beta}_{1}\right)=\beta_{1}+\gamma b$, where $\gamma$ is the coefficient of lagged absenteeism in an absence equation such as equation (1), and $b$ is the slope of a regression that relates the lagged absence rates with the current incidence of variable pay schemes (e.g. equation (3)). Therefore, the estimated negative effect of PRP on current absence, $\beta_{1}$, will be downward-biased when one omits to include lagged absenteeism in the specification, due to the fact that $\gamma$ and $b$ are likely to be positive.
} 
The analysis of this paper draws attention to the fact that only certain types of PRP, particularly those that shift the opportunity cost of absence solely onto the workers' shoulders, are likely to be beneficial as an absence control tool. However, this conclusion does not imply that PRP is a reward instrument that should be universally utilized by all types of firms to prevent worker non-attendance. Whether PRP is a suitable compensation strategy ultimately depends on the production technology of establishments. For example, it is shown that firms that rely on interdependent production should be wary of using PRP to combat absenteeism, and that the potential of PRP is likely to be greater for firms encountering particularly serious absenteeism difficulties.

It is also important to point out that due to data limitations it was not possible to adequately control for endogeneity and for dynamic effects in the absence variable using a suitable instrumental variable (IV) or panel data estimators in the empirical analysis. Nonetheless, the findings reported on the basis of the WERS panel data highlight the need for future research which will decouple the causal chain of reaction between historical rates of absence, the introduction of PRP schemes by firms and their effect on current levels of absenteeism.

\section{References}

Airey, C., Hales, J., Hamilton, R., McKernan, A. and Purdon, S. (1999) 'The Workplace Employee Relations Survey, 1998 (WERS): 1998 Technical Report (Cross Section and Panel Samples)' London: Social and Community Planning Research.

Allen, S.G. (1981) 'An empirical model of work attendance' Review of Economics and Statistics, 63, 7787.

Allen, S.G. (1984) 'Trade unions, absenteeism and exit voice' Industrial and Labor Relations Review, 34, 207-218.

Arai, M. and Thoursie, P.S. (2004) 'Incentives and selection in cyclical absenteeism' Labour Economics, 12, 269-280.

Arrowsmith, J. and Marginson, P. (2011) 'Variable pay and collective bargaining in British retail banking' British Journal of Industrial Relations, 49, 54-79.

Barham, C. and Begum, N. (2005) 'Sickness absence from work in the UK' Labour Market Trends, Office for National Statistics, April: 149-158.

Barham, C. and Leonard, J. (2002) 'Trends and sources of data on sickness absence' Labour Market Trends, Office for National Statistics, April: 177-185.

Barmby, T., Orme, C. and Treble, J.G. (1991) 'Worker absenteeism: an analysis using microdata' Economic Journal, 101, 214-229.

Barmby, T., Orme, C. and Treble, J.G. (1995) 'Worker absence histories: a panel data study' Labour Economics, 2, 53-65. 
Barmby, T., Sessions, J.G. and Tremble, J.G. (1994) 'Absenteeism, efficiency wages and shirking' Scandinavian Journal of Economics, 96, 561-566.

Barmby, T. and Stephan, G. (2000) 'Worker absenteeism: why firm size may matter' Manchester School, 68, 568-577.

Bauer T.K. (2004) 'High performance workplace practices and job satisfaction: evidence from Europe' IZA Discussion Paper, No. 1265, Bonn.

Belfield, R. and Marsden, D. (2003) 'Performance pay, monitoring environments, and establishment performance' International Journal of Manpower, 24, 452-471.

Bender, K.A., Green, C.P. and Heywood, J.S. (2009) 'Piece rates and workplace injury: Does survey evidence support Adam Smith?’ Lancaster University Management School working paper 2010/019.

Bloom, N. and Van Reenen, J. (2010) 'Human resource management and productivity' in O. Ashenfelter and D. Card (eds), Handbook of Labor Economics, Vol. 4, North-Holland, Amsterdam.

Böckerman, P. and Laukkanen, E. (2010) 'What makes you work while you are sick? Evidence from a survey of workers' The European Journal of Public Health, 20, 43-46.

Booth, A. and Frank. J. (1999) 'Earnings, productivity, and performance-related pay' Journal of Labor Economics, 17, 447-463.

Brenčič, V. and Norris, J.B. (2010) 'On-the-job tasks and performance pay: A vacancy-level analysis' Industrial and Labor Relations Review, 63, 511-544.

Brown, S. (1994). 'Dynamic implications of absence behavior' Applied Economics, 26. 1163-1175.

Brown, S. and Sessions, J.G. (1996) 'The economics of absence: theory and evidence' Journal of Economic Surveys, 10, 23-53.

Brown, S., Fakhfakh, F. and Sessions, J.G. (1999) 'Absenteeism and employee sharing: an empirical analysis based on French panel data, 1981- 1991' Industrial and Labor Relations Review, 52, 234-251.

Bryson, A. and Freeman, F. (2010) 'How does shared Capitalism affect economic performance in the United Kingdom?' in: Shared Capitalism at Work: Employee Ownership, Profit and Gain Sharing, and Broad-based Stock Options, Kruse D.L., Freeman R.B., and Blasi J.R., (eds), University of Chicago press: Chicago, US.

Burgess, S. and Rato, M. (2003) 'The role of incentives in the public sector: issues and evidence' Oxford Review of Economic Policy, 19, 285-300.

Chaplin, J., Mangla, J., Purdon, S. and Airey, C. (2005) 'The Workplace Employment Relations Survey 2004 (WERS 2004) Technical Report (Cross Section and Panel Surveys)', London: National Centre for Social Research.

Chartered Institute of Personnel and Development (2009) 'Absence management 2009' available at www.cipd.co.uk

Chatterji, M. and Tilley, C.J. (2002) 'Sickness, absenteeism, presenteeism and sick pay' Oxford Economic Papers, 54, 669-687.

Coles, M., Lanfranchi, J., Skalli, A., and Treble, J.G. (2007) 'Pay, technology and the cost of worker absence' Economic Inquiry, 45, 268-285.

Coles, M.G. and Tremble, J.G. (1996) 'Calculating the cost of absenteeism' Labour Economics 3, 169188.

Dale-Olsen, H. (2009) 'Sickness absence, performance pay and teams' Working Paper, Institute for Social Research, Oslo.

Davies, R. and Welpton, R. (2004) 'Linking the Annual Survey of Hours and Earnings to the 2004 Workplace Employment Relations Survey: A technical discussion with an illustrative analysis of the gender pay gap', WERS 2004 Information and Advice Service Technical Paper No. 3.

Department for Work and Pensions (2002) 'Pathways to Work: Helping people into employment' Cm 5690.

Dione, J. and Dostie, B. (2007) 'New evidence on the determinants of absenteeism using linked employer-employee data' Industrial and Labor Relations Review, 61, 108-120.

Dixit, A. (2002) 'Incentives and organizations in the public sector: an interpretative review' Journal of Human Resources, 37, 696-727. 
Edwards, P. and Greasley, K. (2010) 'Absence from work', Dublin: European Working Conditions Observatory.

Engellandt, A. and Riphahn, R.T. (2011) 'Evidence on incentive effects of subjective performance evaluations' Industrial and Labor Relations Review, 64, 241-257.

Ercolani, M.G. (2006) 'UK employees' sickness absence: 1984-2005' Unpublished manuscript of the HEALTHatWORK EU project (www.abdn.ac.uk/haw).

European Foundation for the Improvement of Living and Working Conditions (EUROFOUND) (1997), 'Preventing Absenteeism at the Workplace: Research Summary', Office for Official Publications of the European Communities: Luxembourg.

Freeman, R.B. and Kleiner, M.M. (2005) 'The last American shoe manufactures: decreasing productivity and increasing profits in the shift to continuous flow production' Industrial Relations, 44, 307-330.

Frey, B.S. (1993) 'Does monitoring increase work effort? The rivalry with trust and loyalty' Economic Inquiry, 31, pp. 663-670.

Frey, B.S. and Jegen, R. (2001) 'Motivation crowding theory: A survey of empirical evidence' Journal of Economic Surveys, 15, 589-611.

Frick, B., Gotzen, U. and Simmons, R. (2008) 'The hidden costs of high performance work practices: evidence from a large German steel company' mimeo.

Gielen, A.C., Kerkhofs, M.J.M and van Ours, J.C. (2010). 'How performance related pay affects productivity and employment', Journal of Population Economics, 23, 291-301.

Gneezy, U. and Rustichini, A. (2000) 'Pay enough or don't pay at all' Quarterly Journal of Economics, $115,791-810$.

Hassink, W. and Koning, P. (2005) 'Do financial bonuses to employees reduce their absenteeism: outcome of a Lottery' Industrial and Labor Relations Review, 62, 327-342.

Henrekson, M. and Persson, M. (2004) 'The effects on sick leave of changes in the sickness insurance system' Journal of Labor Economics, 22, 87-114.

Heywood, J.S. and Jirjahn, U. (2004) 'Teams, teamwork and absence' Scandinavian Journal of Economics, 106, 765-82.

Heywood, J.S., Jirjahn, U. and Wei, X. (2008) 'Teamwork, monitoring and absence' Journal of Economic Behavior and Organization, 68, 676-690.

Holmström, B. (1979) 'Moral hazard and observability' Bell Journal of Economics, 9, 74-91.

Jacobson, S.L. (1989) 'The effects of pay incentives on teacher absenteeism' Journal of Human Resources, 24, 280-286.

Johansson, P. and Palme, M. (1996) 'Do economic incentives affect work absence? Empirical evidence using Swedish micro data' Journal of Public Economics, 59, 195-218.

Kandel, E. and Lazear, E.P. (1992) 'Peer pressure and partnerships' Journal of Political Economy, 100, 801-17.

Kersley, B. Alpin, K. Forth, J. Bryson, A. Bewley, H. Dix, G. Oxenbridge, S. (2006) 'Inside the workplace: findings from the 2004 Workplace Employment Relations Survey'. Routledge.

Kohn, A. (1993) 'Punished by rewards: The trouble with gold stars, incentive plans, A's, praise, and other bribes' Mariner Books.

Lazear, E.P. (1986) 'Salaries and piece rates' Journal of Business, 59, 405-431.

Lazear, E.P. (2000) 'Performance pay and productivity' American Economic Review, 90, 1346-1361.

Leigh, J.P. (1985) 'The effects of unemployment and the business cycle on absenteeism' Journal of Economics and Business, 37, 159-170.

Marsden, D. (2009). 'The paradox of performance related pay schemes: Why do we keep adopting them in the face of evidence that they fail to motivate?' CEP Discussion Paper No 946.

Mcleod, W.B. and Malcomson, J.M. (2000) 'Motivation and markets' American Economic Review, 88, $388-411$.

Milgrom, P. and Roberts, J. (1992) Economics, Organizations and Management: Prentice-Hall: NY.

Millward, N., Stevens, M., Smart, D. and Hawes, W. (1992). 'Workplace Industrial Relations in Transition' Aldershot: Darmouth. 
Murphy, K.J. (1999) 'Executive compensation, in Ashenfelter, O. and Card, D. (Eds), Handbook of Labor Economics, North-Holland, Amsterdam, Vol. 3.

Papke, L.E. and Wooldridge, J.M. (1996) 'Econometric methods for fractional response variables with an application to 401(k) plan participation rates' Journal of Applied Econometrics, 11, 619-632.

Pendleton, A., Whitfield, K. and Bryson, A. (2009) 'The changing use of contingent pay in the modern British workplace' Chapter 11 in W. Brown, A. Bryson, J. Forth and K. Whitfield (eds.) The Evolution of the Modern Workplace, pp. 256-284, Cambridge University Press.

Pouliakas, K. (2010) 'Pay enough, don't pay too much or don't pay at all? The impact of bonus intensity on job satisfaction' Kyklos, 63, 597-626.

Pouliakas, K. and Theodossiou, I. (2009) 'Confronting objections to performance pay: The impact of individual and gain-sharing incentives on job satisfaction' Scottish Journal of Political Economy, 56, 662-684.

Prendergast, C. (1999) 'The provision of incentives in firms' Journal of Economic Literature, 37, 7-63.

Prendergast, C. (2008) 'Intrinsic motivation and incentives' American Economic Review, 98, 201-205.

Schnebller, G.O. and Kopelman, R.E. (1983) 'Using incentives to increase absenteeism: a plan that backfired' Compensation Benefits Review, 15, 40-45.

Seiler, E. (1984) 'Piece rate vs. time-rate: the effect of incentives on earnings' Review of Economics and Statistics, 66, 363-376.

Skatun J.D. (2003) 'Take some days off why don't you? Endogenous sick leave and pay' Journal of Health Economics, 22, 379-402.

Vistnes, J.P. (1997) 'Gender differences in days lost from work due to illness' Industrial and Labor Relations Review, 50, 304-323.

Wilson, N. and Peel, M.J. (1991) 'The impact on absenteeism and quits of profit-sharing and other forms of employee participation' Industrial and Labor Relations Review, 3, 454-468. 

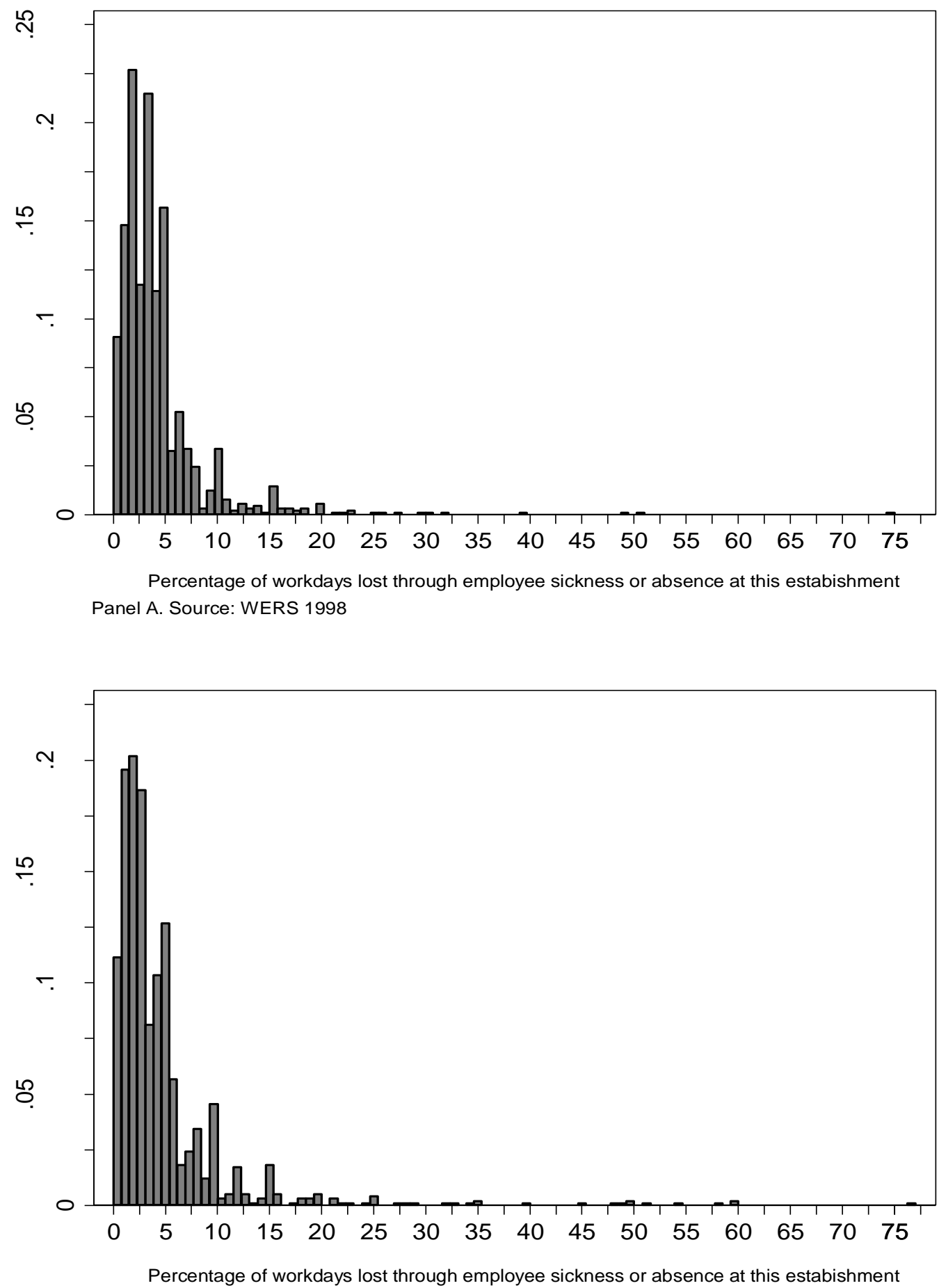

Panel B. Source: WERS 2004

Figure 1. Workplace Absence Distribution

Notes: The exact question was phrased as follows: "Over the past 12 months what percentage of work days was lost through employee sickness or absence at this establishment? Please exclude authorized leave or absence, employees away on secondment or courses, or days lost through industrial action". 
Table 1. Descriptive Statistics (mean, s.d) of Variable Pay Schemes

\begin{tabular}{|c|c|c|}
\hline \multicolumn{3}{|c|}{ Panel A (WERS) } \\
\hline & 1998 & 2004 \\
\hline MP & 0.043 & 0.150 \\
\hline & $(0.202)$ & $(0.358)$ \\
\hline IPBR & 0.125 & 0.209 \\
\hline & $(0.330)$ & $(0.407)$ \\
\hline CPBR & 0.108 & 0.237 \\
\hline & $(0.311)$ & $(0.426)$ \\
\hline PFRP & 0.398 & 0.334 \\
\hline & $(0.490)$ & $(0.472)$ \\
\hline ESO & 0.184 & 0.184 \\
\hline & $(0.387)$ & $(0.388)$ \\
\hline OCB & 0.271 & -- \\
\hline & $(0.445)$ & \\
\hline Observations $(\mathrm{N})$ & 1,192 & 1,281 \\
\hline \multicolumn{3}{|c|}{ Panel B (2004 WERS-ASHE) } \\
\hline Absence Rate & --- & $\begin{array}{c}0.042 \\
(0.039)\end{array}$ \\
\hline Mean Weekly Hours per establishment & --- & $\begin{array}{l}33.31 \\
(6.13)\end{array}$ \\
\hline Mean Annual Gross Earnings per establishment & --- & $\begin{array}{l}24183 \\
(20220)\end{array}$ \\
\hline Mean Hourly Earnings per establishment & --- & $\begin{array}{l}13.14 \\
(6.14)\end{array}$ \\
\hline $\begin{array}{l}\text { Mean Incentive Intensity per establishment } \\
(\mathrm{PRP}>0)\end{array}$ & --- & $\begin{array}{c}0.04 \\
(0.07)\end{array}$ \\
\hline Observations $(\mathrm{N})$ & --- & $\begin{array}{c}\text { All: } 785 \\
\text { Private sector: } 393\end{array}$ \\
\hline \multicolumn{3}{|c|}{ Panel C (WERS Panel 1998-2004) } \\
\hline & 1998 & 2004 \\
\hline MP & $\begin{array}{c}0.074 \\
(0.261) \\
{[r=-0.172 ; p=0.000]}\end{array}$ & $\begin{array}{c}0.531 \\
(0.500) \\
{[r=0.186 ; p=0.000]}\end{array}$ \\
\hline IPBR & $\begin{array}{c}0.151 \\
(0.358) \\
{[r=-0.086: p=0.055]}\end{array}$ & $\begin{array}{c}{[r=0.100, p=0.000]} \\
0.182 \\
(0.386)\end{array}$ \\
\hline CPBR & $\begin{array}{c}0.146 \\
(0.353) \\
{[r=-0.087 ; p=0.052]}\end{array}$ & $\begin{array}{c}{[r=0.011 ; p=0.800]} \\
0.227 \\
(0.419) \\
{[r=-0.069 ; p=0.122]}\end{array}$ \\
\hline PFRP & $\begin{array}{c}0.448 \\
(0.498) \\
{[r=-0.039 ; p=0.381]}\end{array}$ & $\begin{array}{c}0.434 \\
(0.496) \\
{[r=0.030 ; p=0.497]}\end{array}$ \\
\hline ESO & $\begin{array}{c}0.204 \\
(0.403) \\
{[r=-0.049 ; p=0.274]}\end{array}$ & $\begin{array}{c}0.179 \\
(0.383) \\
{[r=-0.072 ; p=0.107]}\end{array}$ \\
\hline Observations (N) & 587 & 587 \\
\hline $\begin{array}{l}\text { Notes. Means are weighted. Standard deviations } \\
\text { present. } r \text { denotes the Pearson pairwise correla } \\
\text { respective PRP scheme in each year of the panel } \\
\text { in the Private sector) remain after merging the W } \\
\text { continuing establishments in the } 2004 \text { WERS Pat }\end{array}$ & $\begin{array}{l}\text { in parentheses. "---" im } \\
\text { coefficients between th } \\
\text { anel weights used]. In Pa } \\
\text { S with the ASHE dataset } \\
\text { Survey are in the private }\end{array}$ & $\begin{array}{l}\text { es that the variable is no } \\
998 \text { absence rate and th } \\
\mathrm{B}, 785 \text { observations }(39 \\
\text { n Panel C, } 587 \text { of the } 95 \\
\text { tor. }\end{array}$ \\
\hline $\begin{array}{l}\text { The statistical results in Panel B remain Crown } \\
\text { as "Source: ONS". }\end{array}$ & yright, and should be ac & wledged either as such o \\
\hline
\end{tabular}


Table 2. Mean of Work Days Lost by Type of Performance Related Pay Scheme

\begin{tabular}{|c|c|c|c|c|c|c|}
\hline & \multicolumn{3}{|c|}{1998} & \multicolumn{3}{|c|}{2004} \\
\hline & Yes & $\mathrm{No}$ & t-test & Yes & $\mathrm{No}$ & t-test \\
\hline MP & $\begin{array}{c}3.198 \\
(2.439)\end{array}$ & $\begin{array}{c}4.226 \\
(4.914)\end{array}$ & 3.086 & $\begin{array}{c}4.111 \\
(4.869)\end{array}$ & $\begin{array}{c}4.885 \\
(6.962)\end{array}$ & 2.189 \\
\hline IPBR & $\begin{array}{c}3.409 \\
(2.255)\end{array}$ & $\begin{array}{c}4.385 \\
(5.225)\end{array}$ & 4.327 & $\begin{array}{c}4.845 \\
(5.908)\end{array}$ & $\begin{array}{c}4.639 \\
(6.716)\end{array}$ & 0.529 \\
\hline CPBR & $\begin{array}{c}3.601 \\
(2.718)\end{array}$ & $\begin{array}{c}4.328 \\
(5.151)\end{array}$ & 2.915 & $\begin{array}{c}4.824 \\
(6.362)\end{array}$ & $\begin{array}{c}4.642 \\
(6.572)\end{array}$ & 0.457 \\
\hline PFRP & $\begin{array}{c}4.081 \\
(3.735)\end{array}$ & $\begin{array}{c}4.348 \\
(5.895)\end{array}$ & 0.909 & $\begin{array}{c}4.640 \\
(6.506)\end{array}$ & $\begin{array}{c}4.732 \\
(6.521)\end{array}$ & 0.251 \\
\hline ESO & $\begin{array}{c}4.407 \\
(4.761)\end{array}$ & $\begin{array}{c}4.098 \\
(4.851)\end{array}$ & 1.051 & $\begin{array}{c}5.076 \\
(6.312)\end{array}$ & $\begin{array}{c}4.522 \\
(6.596)\end{array}$ & 1.430 \\
\hline OCB & $\begin{array}{c}3.769 \\
(3.460) \\
\end{array}$ & $\begin{array}{c}4.407 \\
(5.340)\end{array}$ & 2.474 & --- & --- & --- \\
\hline
\end{tabular}

Notes. Means are weighted. Standard deviations are in parentheses. "----" implies that the variable is not present. 
Table 3. Effect of Performance Related Pay Schemes on Absence Rate

\begin{tabular}{|c|c|c|}
\hline \multicolumn{3}{|l|}{ Panel A (WERS) } \\
\hline Dependent variable: Workplace Absence Rate & 1998 & 2004 \\
\hline \multirow[t]{2}{*}{ MP } & $-0.011 *$ & $-0.008 *$ \\
\hline & $(0.004)$ & $(0.004)$ \\
\hline \multirow[t]{2}{*}{ IPBR } & $-0.010 * *$ & 0.005 \\
\hline & $(0.003)$ & $(0.004)$ \\
\hline \multirow[t]{2}{*}{ CPBR } & 0.0003 & -0.005 \\
\hline & $(0.004)$ & $(0.004)$ \\
\hline \multirow[t]{2}{*}{ PFRP } & -0.005 & -0.004 \\
\hline & $(0.004)$ & $(0.004)$ \\
\hline \multirow[t]{2}{*}{ ESO } & -0.0003 & 0.007 \\
\hline & $(0.004)$ & $(0.005)$ \\
\hline \multirow[t]{2}{*}{ OCB } & $-0.008 * *$ & --- \\
\hline & $(0.003)$ & \\
\hline R-squared & 0.110 & 0.071 \\
\hline Observations $(\mathrm{N})$ & 1,192 & 1,281 \\
\hline \multicolumn{3}{|l|}{ Panel B (WERS) } \\
\hline Proportion of non-managerial employees received PRP in the last 12 months & 1998 & 2004 \\
\hline \multirow[t]{2}{*}{$1 \%$ to $39 \%$} & $-0.008+$ & 0.004 \\
\hline & $(0.004)$ & $(0.007)$ \\
\hline \multirow[t]{2}{*}{$40 \%$ to $79 \%$} & $-0.013 * *$ & 0.005 \\
\hline & $(0.004)$ & $(0.006)$ \\
\hline \multirow{2}{*}{$80 \%$ to $100 \%$} & $-0.012 * *$ & $-0.011^{* *}$ \\
\hline & $(0.003)$ & $(0.004)$ \\
\hline \multirow[t]{2}{*}{ PFRP } & -0.0005 & -0.004 \\
\hline & $(0.004)$ & $(0.004)$ \\
\hline \multirow[t]{2}{*}{ ESO } & -0.001 & 0.007 \\
\hline & $(0.004)$ & $(0.005)$ \\
\hline \multirow[t]{2}{*}{ OCB } & $-0.008 * *$ & \\
\hline & $(0.003)$ & --- \\
\hline R-squared & 0.110 & 0.075 \\
\hline Observations $(\mathrm{N})$ & 1,192 & 1,281 \\
\hline \multicolumn{3}{|l|}{ Panel C (2004 WERS-ASHE) } \\
\hline Proportion of earnings tied to PRP (incentive intensity) & 2004 & 2004 \\
\hline Mean Incentive Intensity per establishment & --- & $\begin{array}{c}-0.138^{* *} \\
(0.044)\end{array}$ \\
\hline \multirow[t]{2}{*}{ Mean Hourly Earnings per establishment } & $-0.076^{*}$ & -0.066 \\
\hline & $(0.037)$ & $(0.047)$ \\
\hline \multirow[t]{2}{*}{ MP } & $-0.010+$ & $-0.011^{*}$ \\
\hline & $(0.005)$ & $(0.005)$ \\
\hline \multirow[t]{2}{*}{ IPBR } & 0.004 & 0.008 \\
\hline & $(0.008)$ & $(0.008)$ \\
\hline \multirow[t]{2}{*}{ CPBR } & -0.012 & -0.011 \\
\hline & $(0.010)$ & $(0.009)$ \\
\hline \multirow[t]{2}{*}{ PFRP } & -0.004 & -0.005 \\
\hline & $(0.006)$ & $(0.005)$ \\
\hline ESO & $0.012+$ & $0.013^{*}$ \\
\hline & $(0.006)$ & $(0.006)$ \\
\hline R-squared & 0.20 & 0.22 \\
\hline $\begin{array}{l}\text { Observations }(\mathrm{N}) \\
\end{array}$ & 390 & 389 \\
\hline
\end{tabular}

Notes: Estimation method is OLS. Estimates are weighted in Panels A and B. In Panel C the weights adjust for the merged ASHE-WERS sample. Robust standard errors are in parentheses. In Panel $\mathrm{C}$ the standard errors are also adjusted for clustering of multiple individuals within the same establishment. Levels of significance: $* * 1 \%$. $* 5 \%,+10 \%$. Full controls for Panel A are presented in Table A3 in the Appendix, while Panels B and C use the same controls. "---" implies that the variable is not present. The dependent variable has been divided by 100 for expositional purposes. Therefore, the size of the coefficient for MP in 1998 implies that firms with that particular variable pay scheme are likely to have a $1.1 \%$ $(0.011 * 100)$ lower absence rate relative to those that do not.

All statistical results in Panel $\mathrm{C}$ remain Crown Copyright, and should be acknowledged either as such or as "Source: ONS". 
Table 4. Sensitivity Analysis - Effect of Performance Related Pay Schemes on Absence Rate

\begin{tabular}{|c|c|c|c|c|c|c|c|c|c|c|c|}
\hline \multirow{3}{*}{$\begin{array}{l}\text { Dependent } \\
\text { variables: } \\
\text { Workplace Absence }\end{array}$} & \multirow{3}{*}{$\begin{array}{c}\begin{array}{c}\text { Organization } \\
\text { fixed effects }\end{array} \\
(1) \\
2004\end{array}$} & \multicolumn{2}{|c|}{$\begin{array}{c}\text { Self- } \\
\text { Selection }\end{array}$} & \multicolumn{2}{|c|}{$\begin{array}{l}\text { Illnesses/ } \\
\text { Injuries }\end{array}$} & \multicolumn{2}{|c|}{ Teamwork } & \multicolumn{2}{|c|}{$\begin{array}{c}\text { Job } \\
\text { satisfaction }\end{array}$} & \multicolumn{2}{|c|}{$\begin{array}{c}\text { Subjective } \\
\text { productivity }\end{array}$} \\
\hline & & \multicolumn{2}{|c|}{ (2) } & \multicolumn{2}{|c|}{ (3) } & \multicolumn{2}{|c|}{ (4) } & \multicolumn{2}{|c|}{ (5) } & \multicolumn{2}{|c|}{ (6) } \\
\hline & & 1998 & 2004 & 1998 & 2004 & 1998 & 2004 & 1998 & 2004 & 1998 & 2004 \\
\hline MP & $\begin{array}{l}-0.035^{*} \\
(-0.015)\end{array}$ & $\begin{array}{l}-0.010^{*} \\
(0.004)\end{array}$ & $\begin{array}{l}-0.008 * \\
(0.004)\end{array}$ & $\begin{array}{l}-0.010^{*} \\
(0.004)\end{array}$ & $\begin{array}{l}-0.009^{*} \\
(0.004)\end{array}$ & $\begin{array}{c}-0.021 * * \\
(0.005)\end{array}$ & $\begin{array}{c}-0.014 * * \\
(0.004)\end{array}$ & $\begin{array}{l}-0.005 \\
(0.006)\end{array}$ & $\begin{array}{l}-0.007 \\
(0.004)\end{array}$ & $\begin{array}{l}-0.010^{*} \\
(0.004)\end{array}$ & $\begin{array}{l}-0.008^{*} \\
(0.004)\end{array}$ \\
\hline IPBR & $\begin{array}{c}0.018 \\
(-0.020)\end{array}$ & $\begin{array}{c}-0.009 * * \\
(0.003)\end{array}$ & $\begin{array}{c}0.005 \\
(0.004)\end{array}$ & $\begin{array}{c}-0.009 * * \\
(0.003)\end{array}$ & $\begin{array}{c}0.005 \\
(0.004)\end{array}$ & $\begin{array}{l}-0.012 * * \\
(0.0004)\end{array}$ & $\begin{array}{c}0.005 \\
(0.004)\end{array}$ & $\begin{array}{l}-0.009^{*} \\
(0.004)\end{array}$ & $\begin{array}{l}-0.001 \\
(0.004)\end{array}$ & $\begin{array}{c}-0.009 * * \\
(0.003)\end{array}$ & $\begin{array}{c}0.005 \\
(0.004)\end{array}$ \\
\hline CPBR & $\begin{array}{c}-0.028 \\
(-0.022)\end{array}$ & $\begin{array}{l}0.0002 \\
(0.003)\end{array}$ & $\begin{array}{l}-0.004 \\
(0.004)\end{array}$ & $\begin{array}{c}0.001 \\
(0.004)\end{array}$ & $\begin{array}{l}-0.005 \\
(0.004)\end{array}$ & $\begin{array}{l}0.0002 \\
(0.004)\end{array}$ & $\begin{array}{l}-0.006 \\
(0.004)\end{array}$ & $\begin{array}{l}-0.001 \\
(0.005)\end{array}$ & $\begin{array}{l}-0.002 \\
(0.004)\end{array}$ & $\begin{array}{c}0.001 \\
(0.004)\end{array}$ & $\begin{array}{l}-0.005 \\
(0.004)\end{array}$ \\
\hline PFRP & $\begin{array}{c}-0.021 \\
(-0.016)\end{array}$ & $\begin{array}{l}-0.005 \\
(0.003)\end{array}$ & $\begin{array}{l}-0.004 \\
(0.004)\end{array}$ & $\begin{array}{l}-0.005 \\
(0.004)\end{array}$ & $\begin{array}{l}-0.004 \\
(0.004)\end{array}$ & $\begin{array}{l}-0.005 \\
(0.004)\end{array}$ & $\begin{array}{l}-0.004 \\
(0.004)\end{array}$ & $\begin{array}{l}-0.007+ \\
(0.004)\end{array}$ & $\begin{array}{l}-0.004 \\
(0.004)\end{array}$ & $\begin{array}{l}-0.005 \\
(0.004)\end{array}$ & $\begin{array}{l}-0.004 \\
(0.004)\end{array}$ \\
\hline ESO & $\begin{array}{c}0.043 \\
(-0.039)\end{array}$ & $\begin{array}{l}-0.0004 \\
(0.004)\end{array}$ & $\begin{array}{c}0.007 \\
(0.004)\end{array}$ & $\begin{array}{l}-0.0002 \\
(0.004)\end{array}$ & $\begin{array}{c}0.007 \\
(0.005)\end{array}$ & $\begin{array}{l}-0.001 \\
(0.004)\end{array}$ & $\begin{array}{c}0.007 \\
(0.005)\end{array}$ & $\begin{array}{l}-0.002 \\
(0.005)\end{array}$ & $\begin{array}{c}0.007 \\
(0.005)\end{array}$ & $\begin{array}{l}0.0001 \\
(0.004)\end{array}$ & $\begin{array}{c}0.007 \\
(0.005)\end{array}$ \\
\hline OCB & --- & $\begin{array}{c}-0.008^{* *} \\
(0.003)\end{array}$ & --- & $\begin{array}{c}-0.009^{* *} \\
(0.003)\end{array}$ & --- & $\begin{array}{c}-0.008 * \\
(0.003)\end{array}$ & --- & $\begin{array}{l}-0.007+ \\
(0.004)\end{array}$ & --- & $\begin{array}{c}-0.008 * * \\
(0.003)\end{array}$ & --- \\
\hline $\begin{array}{l}\text { Percent of same } \\
\text { workforce during } \\
\text { last } 12 \text { months }\end{array}$ & & $\begin{array}{l}-0.005 \\
(0.012)\end{array}$ & $\begin{array}{l}-0.013 \\
(0.009)\end{array}$ & & & & & & & & \\
\hline Percent injury & & & & $\begin{array}{c}0.029 \\
(0.036)\end{array}$ & $\begin{array}{l}-0.002 \\
(0.004)\end{array}$ & & & & & & \\
\hline Percent illness & & & & $\begin{array}{l}0.275^{*} \\
(0.110)\end{array}$ & $\begin{array}{c}0.091 \\
(0.030)\end{array}$ & & & & & & \\
\hline Teamwork & & & & & & $\begin{array}{c}-0.007 * \\
(0.003)\end{array}$ & $\begin{array}{l}-0.004 \\
(0.004)\end{array}$ & & & & \\
\hline Teamwork*MP & & & & & & $\begin{array}{l}0.018^{*} \\
(0.008)\end{array}$ & $\begin{array}{l}0.012+ \\
(0.007)\end{array}$ & & & & \\
\hline Teamwork*IPBR & & & & & & $\begin{array}{c}0.004 \\
(0.005)\end{array}$ & $\begin{array}{c}0.003 \\
(0.006)\end{array}$ & & & & \\
\hline $\begin{array}{l}\text { Mean satisfaction } \\
\text { with influence }\end{array}$ & & & & & & & & $\begin{array}{l}-0.017 \\
(0.016)\end{array}$ & $\begin{array}{l}-0.010 \\
(0.009)\end{array}$ & & \\
\hline $\begin{array}{l}\text { Mean satisfaction } \\
\text { with pay }\end{array}$ & & & & & & & & $\begin{array}{r}-0.006+ \\
(0.003)\end{array}$ & $\begin{array}{r}-0.006+ \\
(0.004)\end{array}$ & & \\
\hline $\begin{array}{l}\text { Mean satisfaction } \\
\text { with achievement }\end{array}$ & & & & & & & & $\begin{array}{c}0.006 \\
(0.006)\end{array}$ & $\begin{array}{c}0.005 \\
(0.008)\end{array}$ & & \\
\hline $\begin{array}{l}\text { Labour } \\
\text { productivity: } \\
\text { lot better/better } \\
\text { than average }\end{array}$ & & & & & & & & & & $\begin{array}{l}-0.003 \\
(0.003)\end{array}$ & $\begin{array}{l}-0.001 \\
(0.004)\end{array}$ \\
\hline R-squared & 0.268 & 0.121 & 0.72 & 0.144 & 0.079 & 0.115 & 0.074 & 0.129 & 0.092 & 0.111 & 0.080 \\
\hline "Observations (N) & 269 & 1,192 & $1,1,281$ & 1,192 & $1,1,281$ & 1,192 & 1,281 & 944 & 938 & 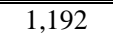 & 1,281 \\
\hline
\end{tabular}

Notes: Estimation method is OLS. Each column controls for the same variables as reported in Table A3 in the Appendix, albeit with the addition of the extra variables as shown in the rows of the Table. Robust standard errors are in parentheses. Levels of significance: **1\%. *5\%, +10\%. "---" implies that the variable is not present. All statistical results in Column 1 remain Crown Copyright, and should be acknowledged either as such or as "Source: ONS". The number of observations in Column 1 are fewer than in the other columns, as the sample is restricted to include only those cases where more than two establishments are part of the same organization. The number of observations in Column 1 are fewer than in the other columns (except column 1) as we merge in information from the employee questionnaire and there is not perfect match. 
Table 5. The Effect of Individual PRP Schemes on Absence Rate - Quintile Regressions

\begin{tabular}{|c|c|c|c|c|c|c|c|c|c|c|}
\hline & \multicolumn{2}{|c|}{$10^{\text {th }}$ quintile } & \multicolumn{2}{|c|}{$25^{\text {th }}$ quintile } & \multicolumn{2}{|c|}{$50^{\text {th }}$ quintile } & \multicolumn{2}{|c|}{$75^{\text {th }}$ quintile } & \multicolumn{2}{|c|}{$90^{\text {th }}$ quintile } \\
\hline & 1998 & 2004 & 1998 & 2004 & 1998 & 2004 & 1998 & 2004 & 1998 & 2004 \\
\hline \multirow[t]{2}{*}{ MP } & $-0.006^{*}$ & $-0.004 * *$ & -0.003 & -0.001 & $-0.004+$ & $-0.005^{* *}$ & $-0.011 * *$ & $-0.006+$ & $-0.017 *$ & $-0.008 *$ \\
\hline & $(0.003)$ & $(0.001)$ & $(0.003)$ & $(0.001)$ & $(0.002)$ & $(0.001)$ & $(0.004)$ & $(0.003)$ & $(0.008)$ & $(0.003)$ \\
\hline \multirow[t]{2}{*}{ IPBR } & 0.002 & 0.002 & -0.001 & 0.001 & $-0.004+$ & 0.0004 & $-0.008^{*}$ & 0.003 & $-0.025 * *$ & 0.006 \\
\hline & $(0.002)$ & $(0.002)$ & $(0.002)$ & $(0.001)$ & $(0.002)$ & $(0.001)$ & $(0.004)$ & $(0.004)$ & $(0.007)$ & $(0.004)$ \\
\hline \multirow[t]{2}{*}{ CPBR } & -0.002 & -0.001 & 0.001 & -0.0003 & 0.002 & -0.001 & -0.001 & -0.001 & 0.006 & -0.001 \\
\hline & $(0.002)$ & $(0.001)$ & $(0.002)$ & $(0.001)$ & $(0.002)$ & $(0.001)$ & $(0.004)$ & $(0.004)$ & $(0.007)$ & $(0.003)$ \\
\hline \multirow[t]{2}{*}{ PFRP } & $0.003 *$ & $0.002 *$ & 0.001 & 0.001 & 0.003 & $-0.0009+$ & 0.003 & -0.0003 & -0.012 & -0.001 \\
\hline & $(0.001)$ & $(0.001)$ & $(0.001)$ & $(0.001)$ & $(0.002)$ & $(0.0006)$ & $(0.003)$ & $(0.003)$ & $(0.007)$ & $(0.003)$ \\
\hline \multirow[t]{2}{*}{ ESO } & -0.001 & 0.0003 & 0.0002 & $0.002+$ & -0.001 & $0.003 * *$ & -0.001 & 0.004 & $0.012+$ & $0.007 *$ \\
\hline & $(0.002)$ & $(0.0012)$ & $(0.001)$ & $(0.001)$ & $(0.002)$ & $(0.001)$ & $(0.003)$ & $(0.004)$ & $(0.006)$ & $(0.003)$ \\
\hline \multirow[t]{2}{*}{ OCB } & -0.001 & --- & 0.0003 & --- & -0.0004 & --- & -0.002 & --- & -0.013 & --- \\
\hline & $(0.001)$ & & $(0.001)$ & & $(0.002)$ & & $(0.002)$ & & $(0.006)$ & \\
\hline Pseudo R-squared & 0.136 & 0.113 & 0.127 & 0.104 & 0.095 & 0.079 & 0.073 & 0.077 & 0.129 & 0.119 \\
\hline $\mathrm{N}$ & 1,192 & 1,281 & 1,192 & 1,281 & 1,192 & $1,1,281$ & $1,1,192$ & $1,1,281$ & 1,192 & 1,281 \\
\hline
\end{tabular}

Notes: The other control variables are the same as those reported in Table A3 in the Appendix. Full estimates are available upon request. Robust standard errors are in parentheses. "---" implies that the variable is not present. For robustness, we also estimated the above regressions by bootstrapping the standard errors using 1,000 replications. The estimates from the bootstrap exercise were very close to the ones reported above and are available upon request. 
Table 6A. Quasi-Panel Estimates (Probit Model): Effect of Absence Rate and Incidence of PRP Schemes in 1998 on Incidence of PRP Schemes in 2004

\begin{tabular}{|c|c|c|c|c|c|c|}
\hline \multirow[b]{2}{*}{ Independent variables } & \multicolumn{6}{|c|}{ Dependent Variables } \\
\hline & MP 04 & IPBR 04 & CPBR 04 & PFRP 04 & ESO 04 & OCB 04 \\
\hline Absence 98 & $\begin{array}{c}0.041 * * \\
(3.38)\end{array}$ & $\begin{array}{c}0.003 * \\
(2.14)\end{array}$ & $\begin{array}{l}-0.003 \\
(-1.18)\end{array}$ & $\begin{array}{l}0.001 \\
(0.07)\end{array}$ & $\begin{array}{c}0.00002 \\
(0.26)\end{array}$ & $\begin{array}{c}-0.0003 \\
(-0.04)\end{array}$ \\
\hline MP 98 & $\begin{array}{c}0.427 * * \\
(4.00)\end{array}$ & $\begin{array}{c}0.123 * \\
(2.19)\end{array}$ & $\begin{array}{c}-0.025^{*} \\
(-2.24)\end{array}$ & $\begin{array}{c}0.626^{* *} \\
(4.29)\end{array}$ & $\begin{array}{c}0.004+ \\
(1.73)\end{array}$ & $\begin{array}{c}0.291 * \\
(2.53)\end{array}$ \\
\hline IPBR 98 & $\begin{array}{l}-0.046 \\
(-0.34)\end{array}$ & $\begin{array}{c}0.085^{*} \\
(2.09)\end{array}$ & $\begin{array}{c}0.210 * * \\
(3.81)\end{array}$ & $\begin{array}{l}-0.027 \\
(-0.20)\end{array}$ & $\begin{array}{c}-0.001 * * \\
(-2.44)\end{array}$ & $\begin{array}{l}-0.027 \\
(-0.51)\end{array}$ \\
\hline CPBR 98 & $\begin{array}{l}-0.064 \\
(-0.53)\end{array}$ & $\begin{array}{l}-0.016 \\
(-1.31)\end{array}$ & $\begin{array}{l}0.043 \\
(1.46)\end{array}$ & $\begin{array}{l}0.161 \\
(1.23)\end{array}$ & $\begin{array}{l}0.001 \\
(0.91)\end{array}$ & $\begin{array}{l}0.051 \\
(0.89)\end{array}$ \\
\hline PFRP 98 & $\begin{array}{c}0.254 * * \\
(2.80)\end{array}$ & $\begin{array}{c}0.049 * * \\
(2.69)\end{array}$ & $\begin{array}{l}0.003 \\
(0.19)\end{array}$ & $\begin{array}{c}0.435^{* *} \\
(5.30)\end{array}$ & $\begin{array}{c}0.003 * * \\
(3.19)\end{array}$ & $\begin{array}{l}0.020 \\
(0.45)\end{array}$ \\
\hline ESO 98 & $\begin{array}{l}-0.057 \\
(-0.54)\end{array}$ & $\begin{array}{l}-0.007 \\
(-0.58)\end{array}$ & $\begin{array}{l}-0.017 \\
(-1.24)\end{array}$ & $\begin{array}{l}-0.152 \\
(-1.43)\end{array}$ & $\begin{array}{c}0.008 * * \\
(4.46)\end{array}$ & $\begin{array}{l}0.054 \\
(1.08)\end{array}$ \\
\hline OCB 98 & $\begin{array}{l}0.042 \\
(0.49)\end{array}$ & $\begin{array}{l}0.001 \\
(0.11)\end{array}$ & $\begin{array}{l}0.016 \\
(1.11)\end{array}$ & $\begin{array}{l}0.058 \\
(0.71)\end{array}$ & $\begin{array}{c}0.0001 \\
(0.33)\end{array}$ & $\begin{array}{c}0.076+ \\
(1.73)\end{array}$ \\
\hline MP 04 & -- & $\begin{array}{l}0.008 \\
(0.73)\end{array}$ & $\begin{array}{c}0.047 * * \\
(2.89)\end{array}$ & $\begin{array}{l}-0.078 \\
(-1.04)\end{array}$ & $\begin{array}{c}-0.0002 \\
(-0.47)\end{array}$ & $\begin{array}{l}0.017 \\
(0.44)\end{array}$ \\
\hline IPBR 04 & $\begin{array}{l}-0.097 \\
(-0.81)\end{array}$ & --- & $\begin{array}{c}0.519 * * \\
(8.71)\end{array}$ & $\begin{array}{l}0.213 \\
(1.53)\end{array}$ & $\begin{array}{c}-0.001 * \\
(-2.36)\end{array}$ & $\begin{array}{l}-0.022 \\
(-0.44)\end{array}$ \\
\hline CPBR 04 & $\begin{array}{c}0.325 * * \\
(2.82)\end{array}$ & $\begin{array}{l}0.443^{*} \\
(7.62)\end{array}$ & --- & $\begin{array}{l}0.183 \\
(1.63)\end{array}$ & $\begin{array}{c}0.013 * * \\
(4.09)\end{array}$ & $\begin{array}{l}-0.042 \\
(-0.94)\end{array}$ \\
\hline PFRP 04 & $\begin{array}{l}-0.067 \\
(-0.80)\end{array}$ & $\begin{array}{c}0.026+ \\
(1.74)\end{array}$ & $\begin{array}{c}0.024+ \\
(1.71)\end{array}$ & --- & $\begin{array}{c}0.003^{* *} \\
(3.69)\end{array}$ & $\begin{array}{l}-0.067 \\
(-1.61)\end{array}$ \\
\hline ESO 04 & $\begin{array}{l}-0.001 \\
(-0.00)\end{array}$ & $\begin{array}{l}-0.016 \\
(-1.56)\end{array}$ & $\begin{array}{c}0.130 * * \\
(3.57)\end{array}$ & $\begin{array}{c}0.351 * * \\
(2.95)\end{array}$ & -- & $\begin{array}{c}-0.076^{*} \\
(-2.01)\end{array}$ \\
\hline OCB 04 & $\begin{array}{l}0.080 \\
(0.94)\end{array}$ & $\begin{array}{l}-0.002 \\
(-0.17)\end{array}$ & $\begin{array}{c}-0.030 * * \\
(-3.04)\end{array}$ & $\begin{array}{l}-0.146 \\
(-1.83)\end{array}$ & $\begin{array}{l}-0.001 \\
(-1.10)\end{array}$ & --- \\
\hline Observations (N) & 434 & 434 & 434 & 434 & 434 & 434 \\
\hline
\end{tabular}

Notes: Reported estimates are marginal effects and t-statistics are in parentheses. 2004 controls are: percentage of: women, part-time employees, trade-union employees, occupational groups; log number of employees, joint consultative committee, quality circles, industry and region fixed effects. 1998 controls include: whether any recognized unions, total number of employees, average duration of the normal working week for full-time largest occupational group, no change activity/takeover etc. since 1998, state of financial performance since 1998, relations between managers and employees at this workplace since 1998. Regression results are applicable to non-managerial employees. Full estimates are available upon request. "---" implies that the variable is not present. 
Table 6B. Quasi-Panel Estimates (Probit Model): Effect of Absence Rate and Incidence of PRP Schemes in 1998 on Incidence of PRP Schemes in 2004 (sample of firms without respective PRP scheme in 1998)

\begin{tabular}{|c|c|c|c|c|c|c|}
\hline \multirow[b]{2}{*}{ Independent variables } & \multicolumn{6}{|c|}{ Dependent Variables } \\
\hline & MP 04 & IPBR 04 & CPBR 04 & PFRP 04 & ESO 04 & OCB 04 \\
\hline Absence 98 & $\begin{array}{c}0.036 * * \\
(2.69)\end{array}$ & $\begin{array}{c}0.0002 * * \\
(3.84)\end{array}$ & $\begin{array}{l}-0.001 \\
(-1.25)\end{array}$ & $\begin{array}{l}-0.002 \\
(-0.72)\end{array}$ & $\begin{array}{c}7.61 \mathrm{e}-07 * \\
(2.51)\end{array}$ & $\begin{array}{l}-0.001 \\
(-0.30)\end{array}$ \\
\hline MP 98 & --- & $\begin{array}{c}0.049 * * \\
(3.40)\end{array}$ & $\begin{array}{c}-0.004 * \\
(-2.39)\end{array}$ & $\begin{array}{c}0.506^{*} \\
(2.52)\end{array}$ & $\begin{array}{c}0.0004 * * \\
(2.56)\end{array}$ & $\begin{array}{l}0.047 \\
(0.65)\end{array}$ \\
\hline IPBR 98 & $\begin{array}{l}-0.002 \\
(-0.02)\end{array}$ & --- & $\begin{array}{c}0.120^{* *} \\
(3.34)\end{array}$ & $\begin{array}{c}0.121+ \\
(1.73)\end{array}$ & $\begin{array}{c}-2.78 \mathrm{e}-06^{*} \\
(-2.54)\end{array}$ & $\begin{array}{c}-0.079 * * \\
(-3.18)\end{array}$ \\
\hline CPBR 98 & $\begin{array}{l}-0.071 \\
(-0.56)\end{array}$ & $\begin{array}{c}-0.0004 \\
(-1.31)\end{array}$ & --- & $\begin{array}{l}0.045 \\
(1.09)\end{array}$ & $\begin{array}{c}0.00002 \\
(1.35)\end{array}$ & $\begin{array}{c}0.309 * * \\
(3.50)\end{array}$ \\
\hline PFRP 98 & $\begin{array}{c}0.289 * * \\
(3.07)\end{array}$ & $\begin{array}{l}0.001 \\
(1.19)\end{array}$ & $\begin{array}{l}0.003 \\
(1.00)\end{array}$ & --- & $\begin{array}{c}0.0001^{* *} \\
(4.66)\end{array}$ & $\begin{array}{c}0.087 * \\
(2.19)\end{array}$ \\
\hline ESO 98 & $\begin{array}{l}-0.035 \\
(-0.31)\end{array}$ & $\begin{array}{l}-0.001 \\
(-1.56)\end{array}$ & $\begin{array}{l}-0.001 \\
(-0.40)\end{array}$ & $\begin{array}{l}-0.006 \\
(-0.17)\end{array}$ & --- & $\begin{array}{c}0.111+ \\
(1.95)\end{array}$ \\
\hline OCB 98 & $\begin{array}{l}0.027 \\
(0.30)\end{array}$ & $\begin{array}{c}-0.0003 \\
(-0.89)\end{array}$ & $\begin{array}{l}0.009^{*} \\
(2.33)\end{array}$ & $\begin{array}{c}0.125 * * \\
(3.36)\end{array}$ & $\begin{array}{c}5.54 \mathrm{e}-06 \\
(1.32)\end{array}$ & --- \\
\hline MP 04 & --- & $\begin{array}{c}6.82 \mathrm{e}-06 \\
(0.02)\end{array}$ & $\begin{array}{l}0.004 \\
(1.51)\end{array}$ & $\begin{array}{l}-0.033 \\
(-0.17)\end{array}$ & $\begin{array}{c}-1.16 \mathrm{e}-06 \\
(-0.56)\end{array}$ & $\begin{array}{l}0.104 \\
(2.87)\end{array}$ \\
\hline IPBR 04 & $\begin{array}{l}-0.111 \\
(-0.88)\end{array}$ & --- & $\begin{array}{c}0.617 * * \\
(7.52)\end{array}$ & $\begin{array}{l}-0.011 \\
(-0.43)\end{array}$ & $\begin{array}{c}-2.43 \mathrm{e}-06^{*} \\
(-2.11)\end{array}$ & $\begin{array}{l}-0.011 \\
(-0.27)\end{array}$ \\
\hline CPBR 04 & $\begin{array}{c}0.329 * * \\
(2.72)\end{array}$ & $\begin{array}{c}0.715 * * \\
(6.69)\end{array}$ & --- & $\begin{array}{c}0.091+ \\
(1.82)\end{array}$ & $\begin{array}{c}0.001 * * \\
(3.91)\end{array}$ & $\begin{array}{l}-0.053 \\
(-1.63)\end{array}$ \\
\hline PFRP 04 & $\begin{array}{l}-0.095 \\
(-1.11)\end{array}$ & $\begin{array}{l}0.002 \\
(1.55)\end{array}$ & $\begin{array}{l}0.006^{*} \\
(2.04)\end{array}$ & --- & $\begin{array}{c}5.63 \mathrm{e}-06^{*} \\
(1.50)\end{array}$ & $\begin{array}{c}-0.097 * * \\
(-3.08)\end{array}$ \\
\hline ESO 04 & $\begin{array}{l}-0.012 \\
(-0.10)\end{array}$ & $\begin{array}{l}-0.001 \\
(-1.37)\end{array}$ & $\begin{array}{l}0.019^{*} \\
(2.43)\end{array}$ & $\begin{array}{c}0.890 * * \\
(4.54)\end{array}$ & --- & $\begin{array}{l}-0.014 \\
(-0.35)\end{array}$ \\
\hline OCB 04 & $\begin{array}{l}0.059 \\
(0.66) \\
\end{array}$ & $\begin{array}{c}-0.0004 \\
(-1.18) \\
\end{array}$ & $\begin{array}{c}-0.005 * * \\
(-2.87) \\
\end{array}$ & $\begin{array}{c}-0.042 * * \\
(-3.24)\end{array}$ & $\begin{array}{c}-1.89 \mathrm{e}-06 \\
(-1.28)\end{array}$ & --- \\
\hline Observations $(\mathrm{N})$ & 408 & 359 & 355 & 160 & 280 & 279 \\
\hline
\end{tabular}

Notes: Reported estimates are marginal effects and t-statistics are in parentheses. 2004 controls are: percentage of: women, part-time employees, trade-union employees, occupational groups; log number of employees, joint consultative committee, quality circles, industry and region fixed effects. 1998 controls include: whether any recognized unions, total number of employees, average duration of the normal working week for full-time largest occupational group, no change activity/takeover etc. since 1998, state of financial performance since 1998, relations between managers and employees at this workplace since 1998. Regression results are applicable to non-managerial employees and to those firms that did not have the respective variable pay scheme in 1998. Full estimates are available upon request. "---" implies that the variable is not present. 


\section{APPENDIX}

\section{Table A1. Definitions of PRP Variables}

\begin{tabular}{|c|c|}
\hline $\begin{array}{l}\text { Whether any employees receive } \\
\text { individual-based merit pay (MP) }\end{array}$ & $\begin{array}{l}\text { 1998: If non-managerial employees have their performance formally appraised and the } \\
\text { performance appraisal is directly linked to reviews or changes in individual employees' } \\
\text { pay and if the appraisals are carried out by an individual's immediate supervisor or } \\
\text { foreman or another manager. } \\
\text { 2004: Do any of the employees at this establishment get paid by results or receive } \\
\text { merit pay? Where 'merit pay' is related to a subjective assessment of individual } \\
\text { performance by a supervisor or manager (therefore is relevant for non-managerial } \\
\text { employees only). }\end{array}$ \\
\hline $\begin{array}{c}\text { Whether any employees receive } \\
\text { individual-based payments-by- } \\
\text { results (IPBR) }\end{array}$ & $\begin{array}{l}\text { 1998: Do any employees at this establishment receive payments or dividends from } \\
\text { individual or group performance-related schemes? Follow-up question asks whether } \\
\text { PRP linked to individual, group or team, workplace, or organization measures for non- } \\
\text { managerial employees. Only the category "individual performance/output" is retained. } \\
\text { 2004: Do any employees at this establishment get paid by results? Follow-up question } \\
\text { asks whether PRP linked to individual, group or team, workplace, or organization } \\
\text { measures of performance for non-managerial employees. Only the category "individual } \\
\text { performance/output" is retained. }\end{array}$ \\
\hline $\begin{array}{l}\text { Whether any employees receive } \\
\text { group or team, establishment or } \\
\text { organization based payments-by } \\
\text { results (CPBR) }\end{array}$ & $\begin{array}{l}\text { 1998: Follow up question on measures of performance used to determine the amount of } \\
\text { PRP used for non-managerial employees. Only the categories "group or team, } \\
\text { workplace, or organization" are retained. } \\
\text { 2004: Follow up question on measures of performance used to determine the amount of } \\
\text { performance-related pay used for non-managerial employees. Only the categories } \\
\text { "group or team, workplace, or organization" are retained. }\end{array}$ \\
\hline $\begin{array}{l}\text { Any profit-related payments or } \\
\text { bonuses (PFRP) } \\
\text { (where workplace is in private } \\
\text { trading sector) }\end{array}$ & $\begin{array}{l}\text { 1998: Do any employees at this workplace receive payments or dividends from any of } \\
\text { the following variable pay schemes: profit-related payments or bonuses; deferred profit } \\
\text { sharing scheme } \\
\text { 2004: Do any employees at this workplace receive profit-related payments or profit- } \\
\text { related bonuses? }\end{array}$ \\
\hline $\begin{array}{l}\text { Any share-ownership schemes } \\
\text { with eligible employees (ESO) } \\
\text { (where workplace is in private } \\
\text { trading sector) }\end{array}$ & $\begin{array}{l}\text { 1998: Do any employees at this workplace receive payments or dividends from } \\
\text { employee share ownership schemes? Eligibility refers to non-managerial employees. } \\
\text { 2004: Does the company operate any of the employee share schemes for any of the } \\
\text { employees at this workplace (SIP, SAYE, EMI, CSOP, Other)? Eligibility refers to } \\
\text { non-managerial employees. }\end{array}$ \\
\hline Other cash bonus (OCB) & $\begin{array}{l}\text { 1998: Do any employees at this workplace receive payments or dividends from any of } \\
\text { the following variable pay schemes: other cash bonus }\end{array}$ \\
\hline
\end{tabular}

Notes: $\mathrm{SIP}=$ Share incentive plan, SAYE=Save as you earn, EMI= Enterprise management incentives, CSOP=Company share option plan, Other= Other employee share scheme 
Table A2. Descriptive Statistics of Control Variables

\begin{tabular}{|c|c|c|}
\hline Variable & 1998 & 2004 \\
\hline \multirow[t]{2}{*}{ Percentage of managers } & 0.094 & 0.114 \\
\hline & $(0.092)$ & $(0.107)$ \\
\hline \multirow[t]{2}{*}{ Percentage of professional staff } & 0.076 & 0.076 \\
\hline & $(0.153)$ & $(0.164)$ \\
\hline \multirow[t]{2}{*}{ Percentage of technical staff } & 0.072 & 0.081 \\
\hline & $(0.130)$ & $(0.161)$ \\
\hline \multirow[t]{2}{*}{ Percentage of clerical and secretarial staff } & 0.138 & 0.142 \\
\hline & $(0.176)$ & $(0.203)$ \\
\hline \multirow[t]{2}{*}{ Percentage of craft and skilled service } & 0.137 & 0.089 \\
\hline & $(0.213)$ & $(0.183)$ \\
\hline \multirow{2}{*}{ Percentage of personal and protective service } & 0.048 & 0.050 \\
\hline & $(0.171)$ & $(0.185)$ \\
\hline \multirow[t]{2}{*}{ Percentage of operative and assembly staff } & 0.182 & 0.127 \\
\hline & $(0.277)$ & $(0.242)$ \\
\hline \multirow[t]{2}{*}{ Percentage of sales staff } & 0.129 & 0.180 \\
\hline & $(0.249)$ & $(0.297)$ \\
\hline \multirow[t]{2}{*}{ Percentage of women } & 0.425 & 0.444 \\
\hline & $(0.278)$ & $(0.285)$ \\
\hline \multirow[t]{2}{*}{ Percentage of part-time employees } & 0.227 & 0.242 \\
\hline & $(0.291)$ & $(0.283)$ \\
\hline \multirow[t]{2}{*}{ Percentage of employees less than 20 years old } & 0.076 & 0.106 \\
\hline & $(0.116)$ & $(0.159)$ \\
\hline \multirow[t]{2}{*}{ Percentage of employees who are members of trade union/independent staff association } & 0.241 & 0.139 \\
\hline & $(0.318)$ & $(0.254)$ \\
\hline \multirow[t]{2}{*}{ Number of employees } & 57.971 & 26.418 \\
\hline & $(213.758)$ & $(88.743)$ \\
\hline \multirow[t]{2}{*}{ Between $1 \%$ to $24 \%$ of employees work on fixed term contracts } & 0.434 & 0.347 \\
\hline & $(0.496)$ & $(0.476)$ \\
\hline \multirow{2}{*}{ More than $25 \%$ of employees work on fixed term contracts } & 0.030 & 0.059 \\
\hline & $(0.171)$ & $(0.236)$ \\
\hline \multirow[t]{2}{*}{ Sick pay in excess of statutory requirements } & 0.578 & 0.494 \\
\hline & $(0.494)$ & $(0.500)$ \\
\hline \multirow[t]{2}{*}{ Specific health and safety committee } & 0.164 & 0.058 \\
\hline & $(0.370)$ & $(0.234)$ \\
\hline \multirow[t]{2}{*}{ Joint consultative committee/work councils/Representative forums } & 0.214 & 0.068 \\
\hline & $(0.410)$ & $(0.252)$ \\
\hline \multirow[t]{2}{*}{ Quality circles/Problem solving groups/Continuous improvement groups } & 0.304 & 0.171 \\
\hline & $(0.460)$ & $(0.377)$ \\
\hline \multirow[t]{2}{*}{ Shift working for non-managerial employees } & 0.301 & 0.210 \\
\hline & $(0.459)$ & $(0.408)$ \\
\hline \multirow[t]{2}{*}{ Annualized hours for non-managerial employees } & 0.025 & 0.032 \\
\hline & $(0.157)$ & $(0.176)$ \\
\hline \multirow[t]{2}{*}{ Unemployment to vacancy ratio by travel to work area } & 3.618 & 3.402 \\
\hline & $(1.627)$ & $(2.463)$ \\
\hline Observations $(\mathrm{N})$ & 1,192 & 1,281 \\
\hline
\end{tabular}

Notes: Means are weighted. Standard deviations are in parentheses. Descriptive statistics on industries and regions are not reported for space considerations but are available upon request. 
Table A3. Effect of Control Variables on Absence Rates (full estimates)

\begin{tabular}{|c|c|c|}
\hline Variable & 1998 & 2004 \\
\hline MP & $\begin{array}{l}-0.011^{*} \\
(0.004)\end{array}$ & $\begin{array}{l}-0.008^{*} \\
(0.004)\end{array}$ \\
\hline IPBR & $\begin{array}{c}-0.010 * * \\
(0.003)\end{array}$ & $\begin{array}{l}0.005 \\
(0.004)\end{array}$ \\
\hline CPBR & $\begin{array}{l}0.0003 \\
(0.004)\end{array}$ & $\begin{array}{l}-0.005 \\
(0.004)\end{array}$ \\
\hline PFRP & $\begin{array}{l}-0.005 \\
(0.004)\end{array}$ & $\begin{array}{l}-0.004 \\
(0.004)\end{array}$ \\
\hline ESO & $\begin{array}{l}-0.0003 \\
(0.004)\end{array}$ & $\begin{array}{c}0.007 \\
(0.005)\end{array}$ \\
\hline OCB & $\begin{array}{c}-0.008^{* * *} \\
(0.003)\end{array}$ & -- \\
\hline Percentage of managers & $\begin{array}{l}-0.025 \\
(0.016)\end{array}$ & $\begin{array}{l}-0.002 \\
(0.018)\end{array}$ \\
\hline Percentage of professional staff & $\begin{array}{l}-0.011 \\
(0.014)\end{array}$ & $\begin{array}{c}-0.033^{*} \\
(0.015)\end{array}$ \\
\hline Percentage of technical staff & $\begin{array}{l}-0.015 \\
(0.012)\end{array}$ & $\begin{array}{c}-0.043^{* *} * \\
(0.015)\end{array}$ \\
\hline Percentage of clerical and secretarial staff & $\begin{array}{l}-0.024+ \\
(0.013)\end{array}$ & $\begin{array}{c}-0.024+ \\
(0.014)\end{array}$ \\
\hline Percentage of craft and skilled service & $\begin{array}{c}0.006 \\
(0.014)\end{array}$ & $\begin{array}{c}-0.023+ \\
(0.012)\end{array}$ \\
\hline Percentage of personal and protective service & $\begin{array}{l}-0.015 \\
(0.011)\end{array}$ & $\begin{array}{c}-0.037 * * \\
(0.013)\end{array}$ \\
\hline Percentage of operative and assembly staff & $\begin{array}{l}0.006 \\
(0.015)\end{array}$ & $\begin{array}{c}-0.025+ \\
(0.013)\end{array}$ \\
\hline Percentage of sales staff & $\begin{array}{c}0.001 \\
(0.014) \\
\end{array}$ & $\begin{array}{l}-0.016 \\
(0.013) \\
\end{array}$ \\
\hline Percentage of women & $\begin{array}{l}0.028^{*} \\
(0.010)\end{array}$ & $\begin{array}{c}0.015 \\
(0.011)\end{array}$ \\
\hline Percentage of part-time employees & $\begin{array}{l}-0.009 \\
(0.010)\end{array}$ & $\begin{array}{l}-0.020^{*} \\
(0.009)\end{array}$ \\
\hline Percentage of employees less than 20 years old & $\begin{array}{l}0.039+ \\
(0.021)\end{array}$ & $\begin{array}{l}0.032+ \\
(0.016)\end{array}$ \\
\hline Percentage of employees who are members of trade union/independent staff association & $\begin{array}{l}0.0003 \\
(0.006)\end{array}$ & $\begin{array}{c}0.014 \\
(0.009)\end{array}$ \\
\hline Log number of employees & $\begin{array}{l}-0.001 \\
(0.002)\end{array}$ & $\begin{array}{l}-0.0004 \\
(0.002)\end{array}$ \\
\hline Between $1 \%$ to $24 \%$ of employees work on fixed term contracts & $\begin{array}{c}0.003 \\
(0.003)\end{array}$ & $\begin{array}{l}-0.001 \\
(0.004)\end{array}$ \\
\hline More than $25 \%$ of employees work on fixed term contracts & $\begin{array}{c}0.003 \\
(0.012)\end{array}$ & $\begin{array}{l}0.0004 \\
(0.011)\end{array}$ \\
\hline Sick pay in excess of statutory requirements & $\begin{array}{l}0.011+ \\
(0.006)\end{array}$ & $\begin{array}{l}-0.001 \\
(0.004)\end{array}$ \\
\hline Specific health and safety committee & $\begin{array}{c}-0.009 * * \\
(0.003)\end{array}$ & $\begin{array}{l}-0.007 \\
(0.005)\end{array}$ \\
\hline Joint consultative committee/work councils/representative forums & $\begin{array}{c}0.012 * * \\
(0.004)\end{array}$ & $\begin{array}{c}0.007 \\
(0.005)\end{array}$ \\
\hline Quality circles/Problem solving groups/Continuous improvement groups & $\begin{array}{l}-0.005+ \\
(0.003)\end{array}$ & $\begin{array}{c}0.002 \\
(0.004)\end{array}$ \\
\hline Shift working for non-managerial employees & $\begin{array}{l}0.014 * \\
(0.006)\end{array}$ & $\begin{array}{r}0.017 * * \\
(0.004)\end{array}$ \\
\hline Annualized hours for non-managerial employees & $\begin{array}{l}-0.009 * \\
(0.004)\end{array}$ & $\begin{array}{l}0.005 \\
(0.007)\end{array}$ \\
\hline Unemployment to vacancy ratio by travel to work area & $\begin{array}{l}0.0002 \\
(0.002)\end{array}$ & $\begin{array}{c}0.00002 \\
(0.001)\end{array}$ \\
\hline Industry fixed effects & Yes & Yes \\
\hline Region fixed effects & Yes & Yes \\
\hline $\begin{array}{l}\text { R-squared } \\
\text { Observations }(\mathrm{N}) \\
\end{array}$ & $\begin{array}{l}0.110 \\
1,192 \\
\end{array}$ & $\begin{array}{l}0.071 \\
1,281 \\
\end{array}$ \\
\hline
\end{tabular}

